\title{
Három nemzetközi kutatás tanulóijóllét-koncepciójának összevetése
}

\author{
Széll Krisztián, ${ }^{*}$ Szabó Lilla** és Róbert Péter***
}

DOI: $10.21549 / N T N Y .33 .2021 .2 .4$

Az utóbbi években (hazai viszonylatban is) egyre növekvő kutatói érdeklődés mutatkozik a gyermekek jólléte iránt, ami különösen igaz az oktatás, iskola kontextusában történő vizsgálatokra. A tanulmány fő célja, hogy átfogó képet adjon a tanulók szubjektív jóllétének lehetséges vizsgálati dimenzióiról, ennek érdekében három nemzetközi kutatás - (1) Gyermekek világa - Nemzetközi vizsgálat a gyermekek jóllétéről (ISCWeB), (2) Iskoláskorú gyermekek egészségmagatartása (HBSC), (3) Tanulói teljesítmények nemzetközi értékelésének programja (PISA) - jóllétkoncepcióját, valamint a felmérések legutóbbi adatfelvételeiben vizsgált tanulói jóllétdimenziókat veti össze. Összességében megállapítható, hogy a tanulói jóllét vizsgálatát mindhárom felmérés többdimenziós keretbe ágyazza, így számos közös terület (élettel való általános elégedettség, érzelmi állapot, pszichológiai jóllét, családi élet, baráti kapcsolatok, iskolai élet, egészségi állapot, szubjektiv és objektív testkép) megjelenik az adatfelvételekben. Az összehasonlítás eredménye azt mutatja, hogy a felmérések jólléthez köthető kérdései nem minden esetben feleltethetők meg teljesen egymásnak, több esetben inkább csak tartalmi, funkcionális megfeleltetés lehetséges. Emellett a vizsgált tanulók életkora, a tanu lók jóllétére vonatkozó kérdések kontextusa is eltérő ezekben a felmérésekben. Különbség mutatkozik az egyes dimenziókhoz tartozó kérdések, illetve itemek számában, a válaszlehetőségként megadott kategóriákban (skálák fokozatában), valamint abban is, hogy az egyes adatfelvételek milyen idöintervallumra vonatkoztatva kérdeznek rá bizonyos jelenségek elöfordulására. Mindezek ellenére tanulmányunk első lépés abba az irányba, hogy a későbbiekben ezen nemzetközi felmérések eredményei alapján megpróbáljunk megbízhatóbb és érvényesebb képet alkotni a tanulók jóllétéről, különös tekintettel a magyar jellegzetességekre.

Kulcsszavak: tanulói jóllét, jóllétdimenziók, nemzetközi összehasonlítás, ISCWeB, HBSC, PISA

\section{Bevezetés}

Az elmúlt évtizedekben a tanulók életminőségével foglalkozó kutatásokban is egyre erőteljesebben jelentek meg a különböző jóllétkoncepciókra épülő megközelítések. A kutatások a gyermekek életminőségét általában objektiv (például anyagi erőforrások, életkörülmények) és (készítettem hozzá egy áttekintőt a biztonság kedvéért, ezt is küldöm) /vagy szubjektív (affektív és kognitív elemeket tartalmazó hedonikus (Ryan \& Deci, 2001), illetve az önmegvalósítást fókuszba helyező eudaimonikus (Huppert, 2014) aspektusból közelítik meg (Huppert, 2014; Veenhoven, 2007), hozzátéve, hogy a szubjektív megközelítés, különösen a 2010-es évet követően kapott egyre nagyobb figyelmet (Cho \& Yu, 2020). A tendencia erősödését támogatta a pozitív pszichológia, illet ve az ezen alapuló pedagógiai megközelítés térnyerése. A pozitív pszichológián alapuló pedagógiai megközelí-

\footnotetext{
Egyetemi adjunktus, ELTE PPK, Neveléstudományi Intézet, e-mail: szell.krisztian@ppk.elte.hu

** Doktori hallgató, ELTE PPK, Neveléstudományi Intézet, Neveléstudományi Doktori lskola, e-mail: szabo.lilla@ppk.elte.hu

*** Egyetemi tanár, programvezető kutató, TÁRKI Zrt, e-mail: robert@tarki.hu
} 
tés alapvetően arra fókuszál, hogy milyen környezeti és belső feltételek szükségesek a pozitív életérzésekhez, a motiváció megtartásához, az egyéni és közösségi jólléthez (Hamvai \& Pikó, 2008; Noble \& McGrath 2008; Oláh \& Kapitány-Fövény, 2012; Seligman \& Adler, 2019).

A tanulói jóllét többdimenziós fogalom, amely rövid és hosszútávon, vagyis aktuális helyzetekre adott reakcióként és egy folyamat eredményeként is értelmezhető, s magában foglalja az általános tanulási- és élettapasztalatokat is (Bourke \& Geldens, 2007; Awartani, Whitman \& Gordon, 2008). A gyermekek, tanulók jóllétének többdimenziós, interdiszciplináris jellegét jól mutatja a fogalom tudományterületek, illetve az egyes elemzések szerint is eltérő koncepcionalizálása (jogi, egészségközpontú, fejlődési, ökológiai, képességalapú stb. megközelítések) és operacionalizálása (vizsgált dimenziók és indikátorok száma - Cho \& Yu, 2020). Ugyanakkor a szakirodalomban, kutatásokban közös dimenziók - például bizonyos személyes (fizikai-egészségügyi állapot, pszichológiai, kognitív tényezők stb.) és kontextuális (társas kapcsolatok, iskolai körülmények, társadalmi-gazdasági háttér, környezeti tényezők stb.) dimenziók - is megjelennek (Konu, Lintonen \& Rimpelä, 2002; Pollard \& Lee, 2003; Soutter, O'Steen \& Gilmore, 2014).

A gyermek jólléte, általános közérzete, elégedettsége az otthon, az iskolában, valamint a szǔkebb és tágabb környezetben átélt szubjektív élményeken keresztül hatást gyakorol testi-lelki egészségére, fejlődésére, viselkedésére (Williams, Holmbeck \& Greenley, 2002; Örkényi \& Koszonits, 2004), valamint pozitív kapcsolatba hozható a tanulással, az iskolai teljesítménnyel is (Konu, Lintonen \& Rimpela, 2002; Vieno, Santinello, Galbiati \& Mirandola, 2004; Seligman et al., 2009). A tanulók szubjektív jólléte tehát alapvető fontosságú mind a tanulmányi teljesítmény, mind a szociális készségek fejlesztésében. Többek között ezért is nagyon fontos, hogy mi nél több ismeret, empirikus eredmény álljon rendelkezésre a tanulók jóllétéről. Az elmúlt években hazai viszonylatban is egyre növekvő kutatói érdeklődés mutatkozik a gyermekek jólléte iránt, ami különösen igaz az oktatás, iskola kontextusában történő vizsgálatokra (Örkényi \& Koszonits, 2004; Szabó, 2016; Nagy, 2018; Nagy et al., 2019). A növekvő érdeklődést jól mutatja, hogy egyre több, nemcsak egyes országokon belül, ha nem nemzetközi szinten végzett kutatás - melyben Magyarország is részt vesz - tér ki a különféle jólléti di menziók vizsgálatára.

Tanulmányunk fő célja, hogy átfogó képet adjon a tanulók szubjektiv jóllétének lehetséges vizsgálati dimenzióiról. Ehhez alapvető támpontot ad az olyan nemzetközi felmérések vizsgálata, amelyek fókuszában a tanulói jóllét feltérképezése is megjelenik, $s$ amelyek kisebb-nagyobb mértékben eltérő elméleti és módszertani megközelítésből vizsgálódnak. Ennek megfelelően tanulmányunk az egyes jóllétdimenziókat három nemzetközi kutatás jóllétkoncepciójának összehasonlításával mutatja be: (1) Gyermekek világa - Nemzetközi vizsgálat a gyermekek jóllétéröl (Children's Worlds International Survey of Children's Well-being, ISCWeB), (2) Iskoláskorú gyermekek egészségmagatartása (Health Behaviour in School-aged Children, HBSC) és (3) Tanulói teljesítmények nemzetközi értékelésének programja (Programme for International Student Assessment, PISA). Tanulmányunkban először a három kutatás koncepcionális hátterét vázoljuk fel, kitérve az egyes felmérések módszertani jellegzetességeire is, majd ezt követően összehasonlítjuk a három kutatásban megjelenő jóllétdimenziók, tanulói jólléttel kapcsolatos témák és kérdések körét. 


\section{Fóllétkoncepciók a vizsgált nemzetközi kutatásokban}

\section{Gyermekek világa - Nemzetközi vizsgálat a gyermekek jóllétéről (ISCWeB)}

Az ISCWeB nemzetközi felmérés ${ }^{1}$ a gyermekek nézőpontjából tárja fel a 8, 10 és 12 éves gyermekek saját életükről, mindennapi tevékenységeikről (otthon, iskolában, szabadidőben, baráti körben), időfelhasználásukról, szubjektív és pszichológiai jóllétükről alkotott percepcióit. A felmérés reprezentatív adatokra támaszkodva törekszik arra, hogy felhívja a figyelmet a gyermekek jóllétének fontosságára egyrészt saját maguk, szüleik, szűkebb (baráti, iskolai) közösségeik, másrészt a döntéshozók, a szakértők és a szélesebb közönség számára. Nemzetközi kutatás lévén célként és előnyként jelenik meg az egyes országok összehasonlíthatósága is (Casas, 2019).

A projekt 2009-ben indult olyan intézményi háttérrel, mint az UNICEF vagy az International Society for Child Indicators (ISCI). A kezdetekben német, angol, izraeli, spanyol és román kutatók alakították ki a kutatás alapkoncepcióját. A 2011-ben megvalósuló első adatfelvételi hullámban 14 ország vett részt, melyek között az alapkoncepciót kialakító országokon kívül főleg Európán kívüli országok (például az USA és Kanada) szerepel tek. A második hullámban, 2013-2014-ben már 21 országban került sor adatfelvételre, ekkor több európai or szág csatlakozott a felméréshez főként Skandináviából és Dél-Európából. A felmérés harmadik, 2016 és 2019 között zajlott hullámában tovább bővült az országok (régiók) listája, ekkor már 35 ország (régió), köztük Ma gyarország részvételével zajlott a felmérés. ${ }^{2}$ A harmadik adatfelvételi hullám így csaknem 127000 (körülbelül 33000 nyolcéves, 47500 tízéves és 46000 tizenkét éves) gyermek véleményét gyüjtötte össze.

A kutatás módszertani megvalósítása során fontos kritérium a reprezentativitás, ugyanakkor az egyes országok (régiók) mintavételi eljárása nem egységes, hanem igazodik az adott országok (régiók) eltérő sajátosságaihoz. A mintanagyság kapcsán elvárás, hogy mindhárom vizsgált korosztályban legalább 1000 fő kerüljön a mintába. Magyarországon kétlépcsős rétegzett mintavételre került sor: az általános iskolák rétegzése településtípus, földrajzi elhelyezkedés (régió), fenntartó és iskolaméret alapján történt, ezt követően az iskolák véletlenszerúen kerültek kiválasztásra. A kiválasztott iskolák 3., 5. és 7. évfolyamos tanulói szülói engedéllyel vettek részt a vizsgálatban. A magyar mintát 75 általános iskola összesen 3045 tanulója alkotja: 1016 fő a 3. évfolyamról, 1035 fő az 5. évfolyamról és 994 fó a 7. évfolyamról.

Az ISCWeB kutatás jóllétkoncepciójának egyik fontos eleme a jóllét fogalom hedonikus (boldogsággal, örömmel, elégedettséggel azonosító) és eudaimonikus (a boldogságnál többnek tartó, a kiteljesedéssel és nö vekedéssel azonosító) felfogásának megkülönböztetése (Ryan \& Deci, 2001; Deci \& Ryan, 2008). Az ISCWeB harmadik adatfelvételi hulláma a gyermekek jóllétének három aspektusát vizsgálja: (1) a szubjektív jóllét affektív komponensét (Kahneman, Diener \& Schwarz, 1999), mely a megélt pozitív és negatív érzelmeket öleli fel, és a jóllét kevésbé stabil, inkább változékony összetevője, (2) a szubjektív jóllét kognitív komponensét (Kahneman, Diener \& Schwarz, 1999), mely az élettel való általános elégedettségre és az élet egyes területeivel kapcsolatos elégedettségre vonatkozó, stabilabb komponens, valamint (3) a pszichológiai jóllétet (Ryff, 1989), mely a személyes fejlődésre, növekedésre fókuszál, és integrálja az önelfogadás, az autonómia, a másokkal való jó kapcsolat, a környezet uralása, az életcélok és a személyes fejlődés területeit. A hedonikus jóllétfelfogáshoz a szubjektív jóllét affkektív és kognitiv elemei (Kahneman, Diener, \& Schwarz, 1999), az eudaimonikus jóllétfelfogáshoz pedig a pszichológiai jóllét elemei (Ryff, 1989) kapcsolódnak szorosan (1. ábra).

1. A kutatás honlapja: https://isciweb.org/

2. 2020-ban az első eredmények hazai publikálására is sor került (Róbert, Szabó \& Széll, 2020). 


\section{JÓLLÉT}
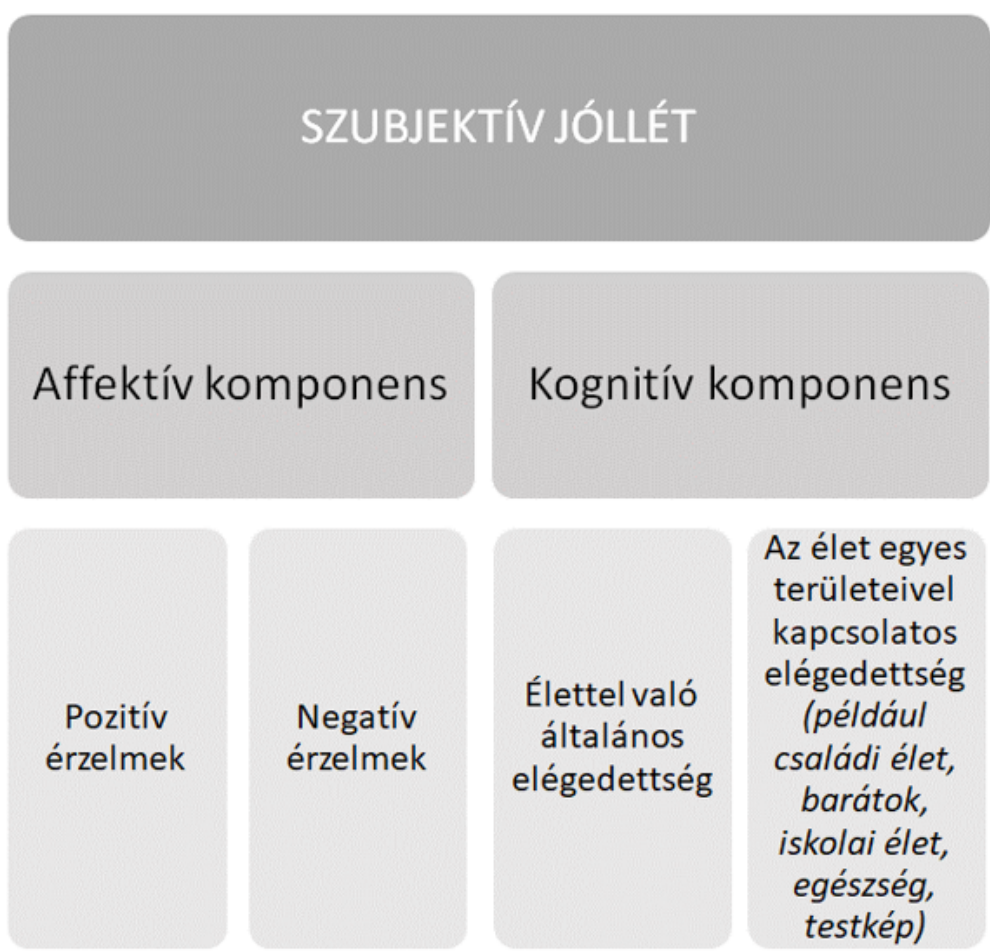

\section{Kognitív komponens}

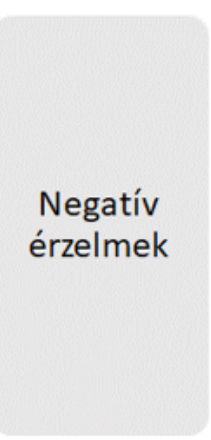

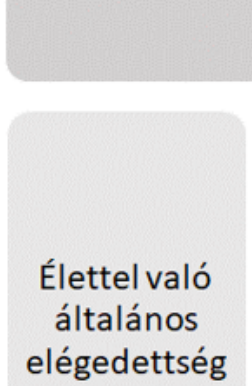

Az élet egyes
területeivel
kapcsolatos
elégedettség
(például
családi élet,
barátok,
iskolai élet,
egészség,
testkép)

PSZICHOLÓGIAI JÓLLÉT
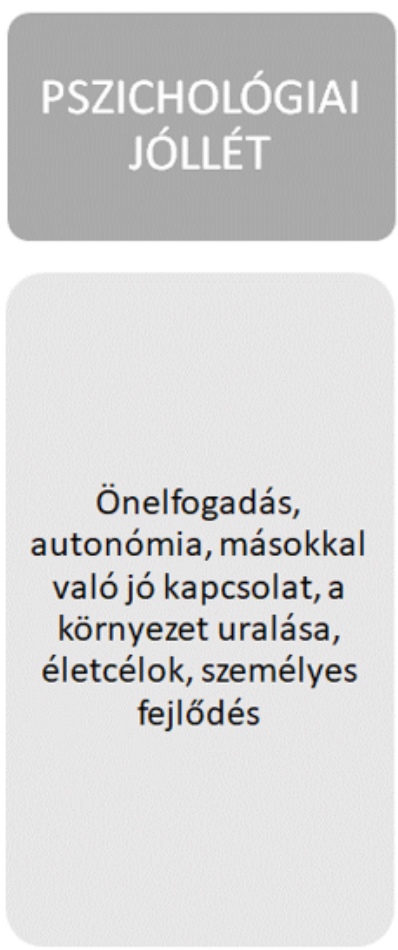

1. ábra: Jóllétkoncepció az ISCWeB kutatásban (saját szerkesztés Rees et al., 2013 alapján)

A jóllétkoncepció alapján az ISCWeB kutatás a gyermekek életének 12 területéről gyűjt adatot: (1) maga a gyermek, (2) a család, illetve gyermekkel együtt élő személyek, (3) az otthon, (4) a barátok, (5) az iskola, (6) a környék, ahol a gyermek él, (7) az élet egyes aspektusaival való elégedettség, (8) az élettel való általános elégedettség, (9) a pénz és a család vagyoni helyzete, (10) a szabadidő, (11) élet a saját országában, (12) egyéb terület.

\section{Iskoláskorú gyermekek egészségmagatartása (HBSC)}

A HBSC nemzetközi kutatás ${ }^{3}$ a serdülőkorú tanulók életmódját vizsgálja. Fő célja, hogy megismerje a kamaszok szubjektív egészségi állapotát, jóllétét, egészségmagatartását és mindazon egyéni, illetve fizikai és társas kör nyezeti tényezőket, melyek hatást gyakorolhatnak mindezekre. A kutatás széles értelemben tekint a kamaszok egészségére, ideértve fizikai, lelki, érzelmi és társas jóllétüket mint a mindennapi élethez szükséges erőforrásokat. A kutatás nyomon követi a fiatalok szélesebb társadalmi-gazdasági kontextusban értelmezett egészségmagatartását (Németh \& Várnai, 2019).

A HBSC-kutatás több mint 35 éve indult a WHO-val együttműködésben. Az adatgyüjtés négyévente, 11, 13 és 15 éves tanulók körében zajlik, a legutóbbi alkalommal már csaknem 50 tagország részvételével valósult meg. Magyarország 1985-ben csatlakozott a vizsgálathoz, azóta minden soron következő alkalommal teljesült 
az országosan reprezentatív adatgyűjtés, vagyis a legutóbbi, 2018-ban végzett adatfelvétel már a kilencedik volt Magyarországon (Németh \& Várnai, 2019; Inchley et al., 2020). Az adatfelvétel minden részt vevő országban, illetve régióban a nemzetközi kutatási protokollban előírtak szerint zajlott, így az életkori megoszlás szerinti reprezentativitást csoportos mintavétellel biztosították. A tanulói minták nagysága korcsoportonként körülbelül 1500 fő minden országban (régióban) (Inchley, Currie, Cosma \& Samdal, 2018). A legutóbbi adatgyűjtés alkalmával összesen közel 228000 (körülbelül 7700011 éves, 7800013 éves és 7200015 éves) tanuló töltötte ki a kérdőívet. A magyar felmérésbe csaknem 6000 (1575 5. évfolyamos, 1662 7. évfolyamos és 1627 9. évfolyamos, s kiegészítésként 1139 11. évfolyamos) tanulót vontak be. A településtípusra, földrajzi régióra, valamint iskolákra reprezentatív tanulói minta rétegzett mintavételi eljárással készült. A tanulók névtelenül, önkéntesen, szülői beleegyezéssel vettek részt az adatfelvételben (Németh \& Várnai, 2019).

A kutatás során felvett kérdőív több részből áll össze. A részt vevő országok kutatócsoportja által elfogadott nagyobb kérdéscsomag kötelező eleme a felmérésnek, egyaránt tartalmaz a korábbi adatfelvételekben alkalmazott kérdéseket és újakat is. A vizsgálatba bevont témák köre folyamatosan bővül, változik, reflektálva a technológiai és társadalmi folyamatokra, változásokra. Ennek megfelelően lehetőség van további, választható kérdéscsomagok adaptálására is, melyek lehetővé teszik egy-egy téma mélyebb vizsgálatát. Ezen felül az adott országot képviselő kutatócsoport egyéb területekkel és kérdésekkel is kiegészítheti a kérdőívet. A HBSC-kutatás keretében vizsgált témaköröket a 2. ábrán foglaltuk össze.

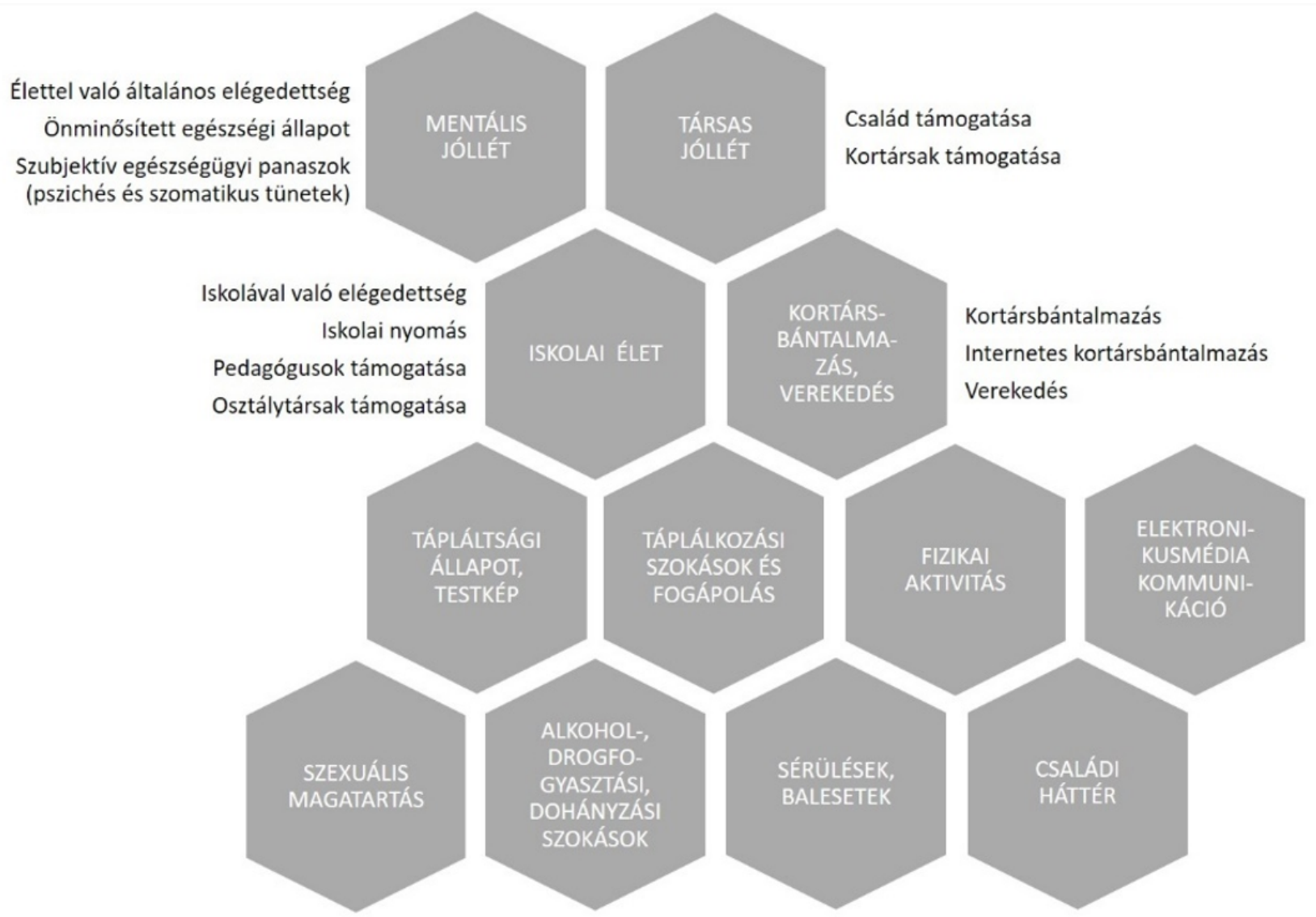

2. ábra: Egészségmagatartás-koncepció a HBSC-kutatásban (saját szerkesztés Németh \& Várnai, 2019 és Inchley et al., 2020 alapján) 
A legutóbbi, 2018. évi adatfelvétel a szubjektív jóllétet, ezen belül az élettel való elégedettséget mint a mentális jóllét egy összetevőjét vizsgálta. Kapcsolódó területként többek között megjelent a társas jóllét (indikátorai: család és kortársak támogatása), az iskolai tapasztalatok (indikátorai: iskolával való elégedettség, iskolai nyomás, tanárok és osztálytársak támogatása), a szubjektív és objektív testkép, a szubjektív egészségi állapot és a kortársbántalmazás (Inchley et al., 2020). A magyar adatfelvételben a szubjektív jólléthez kapcsolódóan az alvási szokásokról, a krónikus betegségekről és állapotokról (választható kérdéscsomagok), valamint a depreszszív tünetekről (kutatócsoport által beemelt kérdésblokk) is megkérdezték a tanulókat (Németh \& Várnai, 2019).

\section{Tanulói teljesítmények nemzetközi értékelésének programja (PISA)}

A PISA-vizsgálatot ${ }^{4}$ az OECD indította el 2000-ben, OECD-országok és -partnerországok közremüködésével. A mérés populációját azok a 15 éves diákok jelentik, akiknek életkora az adatfelvétel idején 15 év 3 hónap és 16 év 2 hónap közötti, és legalább 6 tanévet befejeztek formális oktatási keretek között, iskolatípusra való tekin tet nélkül. A felmérés általános célja annak vizsgálata, hogy a 15 éves tanulók a tankötelezettség végéhez kö zeledve milyen mértékben rendelkeznek azokkal a képességekkel és ismeretekkel, melyek elősegítik társadalmi és munkaerőpiaci beilleszkedésüket. Ennek megfelelően a mérés során azt vizsgálják, hogy a tanulók mennyire tudják alkalmazni, hasznosítani az iskolában elsajátított tudást a gyakorlatban, a mindennapi helyzetekben. További célként jelenik meg a részt vevő országok oktatási rendszerei teljesítményének és egyéb jellemzőinek összehasonlítása is (Oktatási Hivatal, 2019). A PISA által kifejlesztett minőségi standardok, eljárások, eszközök és ellenőrzési mechanizmusok biztosítják, hogy a nemzeti minták összehasonlítható adatokat szolgáltassanak, és az eredmények országok (régiók) között is megbízhatóan összevethetők legyenek (OECD, 2019a, 2019b).

Az adatfelvételre háromévenként kerül sor, Magyarország a kezdetektől minden alkalommal részt vett a vizsgálatban. A legutóbbi, immár hetedik mérés 79 ország részvételével valósult meg 2018-ban, amikor is körülbelül 600000 tanuló reprezentálta a részt vevő országok és régiók 32 millió 15 éves tanulóját (OECD, 2019b). A magyar tanulói mintát 245 iskola 5132 tanulója alkotta, akiknek többsége 9. évfolyamos volt ( $\mathrm{N}=3$ 800), de az adatfelvételben általános iskolába járó 7. és 8. évfolyamos $(N=324)$, illetve 10. évfolyamos $(N=1$ 006) és 11. évfolyamos ( $N=2$ ) tanulók is részt vettek (Oktatási Hivatal, 2019).

Bár a PISA-vizsgálat fő területei a szövegértés, az alkalmazott matematikai műveltség és az alkalmazott természettudományi múveltség, a kutatás a tanulókról és az iskolai környezetről is gyŭjt adatokat különböző (ta nulói, igazgatói) háttérkérdőívek segítségével, megteremtve ezzel az átfogóbb, komprehenzív vizsgálódás lehetőségét. A PISA sajátossága, hogy az egyes mérések alkalmával egy-egy múveltségi terület nagyobb hangsúlyt kap, valamint a klasszikus mérési területek mellett minden alkalommal megjelennek kapcsolódó területek, kompetenciák. 2018-ban a 15 évesek globális kompetenciájának fejlettségét vizsgálták a klasszikusnak számító területek mellett, azonban a magyarországi adatfelvétel nem terjedt ki e kompetencia mérésére. A PISA lehetőséget biztosít a részt vevő országok számára, hogy kiegészítő (tanári, illetve szülői kérdőívek) és választható (számítógépes ismeretek, továbbtanulási aspirációk és elvárások, illetve tanulói jóllét feltárását célzó) kérdőíveket is beemeljenek a nemzeti mérésbe a standard tesztek és háttérkérdőívek mellé.

A tanulói jólléttel kapcsolatos választható kérdőívet,"s mely a standard kérdőívben szereplő tanulói jóllétet mérő itemekhez képest mélyebb vizsgálatra ad lehetőséget, mindössze kilenc ország (Magyarország nem volt

4. A kutatás honlapja: https://www.oecd.org/pisa/

5. A kérdőív angol változata itt érhető el: https://www.oecd.org/pisa/data/2018database/CY7_201710_QST_MS_WBQ_NoNotes_final.pdf 
köztük) adaptálta 2018-ban. A PISA-vizsgálatban a tanulók jólléte azokra a pszichológiai, kognitív, anyagi, társadalmi és fizikai müködésekre és képességekre utal, amelyekre a tanulóknak szükségük van ahhoz, hogy boldog és teljes életet éljenek. Ebben az értelmezési keretben a jóllét dinamikus állapot: a képességek fejlesztésébe történő jelenlegi erőforrásbefektetés, odafigyelés nélkül a tanulók kisebb eséllyel élvezhetik majd felnőttként a jóllét magas szintjét. A PISA-vizsgálatban a tanulói jóllét elemzésének keretein belül a tanulók jóllétének öt területét azonosítják: (1) kognitív jóllét (például tudás, alapkészségek), (2) pszichológiai jóllét (például iskola kötődés, jövőbeni célok és ambíciók), (3) fizikai jóllét (például egészségi állapot, fizikai tevékenységek), (4) társas jóllét (például kapcsolat a családdal, a társakkal és a tanárokkal) és (5) anyagi jóllét (például anyagi erőforrá sok) (Borgonovi \& Pál, 2016; OECD, 2019b).

A kognitiv jóllét azokat a képességeket, tudást és alapokat foglalja magába, melyek birtokában a serdülők a társadalomban - mint élethosszig tanulók - hatékony munkavállalók- és elkötelezett polgárokként tevékenykednek. A pszichológiai jóllét felöleli a tanulók életükkel, iskolai kötődésükkel, céljaikkal és a jövőjükre vonatko zó törekvéseikkel kapcsolatos értékítéleteit és nézeteit. A fizikai jóllét dimenziója a serdülők egészségi állapotára, valamint az egészségtudatos táplálkozás és a testmozgás iránti elköteleződésükre utal. A társas jóllét a kamaszok szociális életére utaló konstruktum, mely magában foglalja a családdal, kortársakkal, pedagógusokkal való kapcsolatot és az iskolai társas élet szubjektív megítélését. Az anyagi jóllét mindazokat a család, illetve iskola rendelkezésére álló erőforrásokat öleli fel, melyek alkalmasak a gyermekek szükségleteinek kielégítésére, tanulásuk és egészséges fejlődésük támogatására (Borgonovi \& Pál, 2016).

A PISA 2018-ban tanulói jóllét mérésére kialakított keret a jóllét különböző megközelítéseit ötvözi magában, annak különböző dimenzióit számos indikátorral ragadja meg. Ez a keretrendszer modulokra bontható egyfelől dimenziók szerint (én, iskolai környezet, iskolán kívüli környezet), másfelől az indikátor típusa - objektív vagy szubjektív (percepció, érzelem, elégedettség) - szerint. Objektív komponensei az egyénre és a környe zetre vonatkozó materiális/szociális indikátorokkal írhatók le (például a háztartás jövedelme, oktatási erőforrások, egészségi állapot), szubjektív komponensei ugyanakkor az élettel, a szubjektummal és a környezettel kapcsolatos érzelmeket, percepciókat és elégedettséget jelölik. A dimenzió és indikátorjelleg kettőséből képzett egységek, melyek maguk is indikátorok, együttesen összetett indikátorokként is használhatók, alkalmazásukkal lehetővé válik a jelenség komplexebb, fókuszáltabb megközelítése. Ilyen összetett indikátor lehet például az általános jóllét, a szubjektív jóllét, a társas jóllét és az iskola-magánélet egyensúlya (OECD, 2019a). A PISA-vizsgálat jóllétkoncepciójának moduláris jellegú keretrendszerét a 3. ábra szemlélteti. 


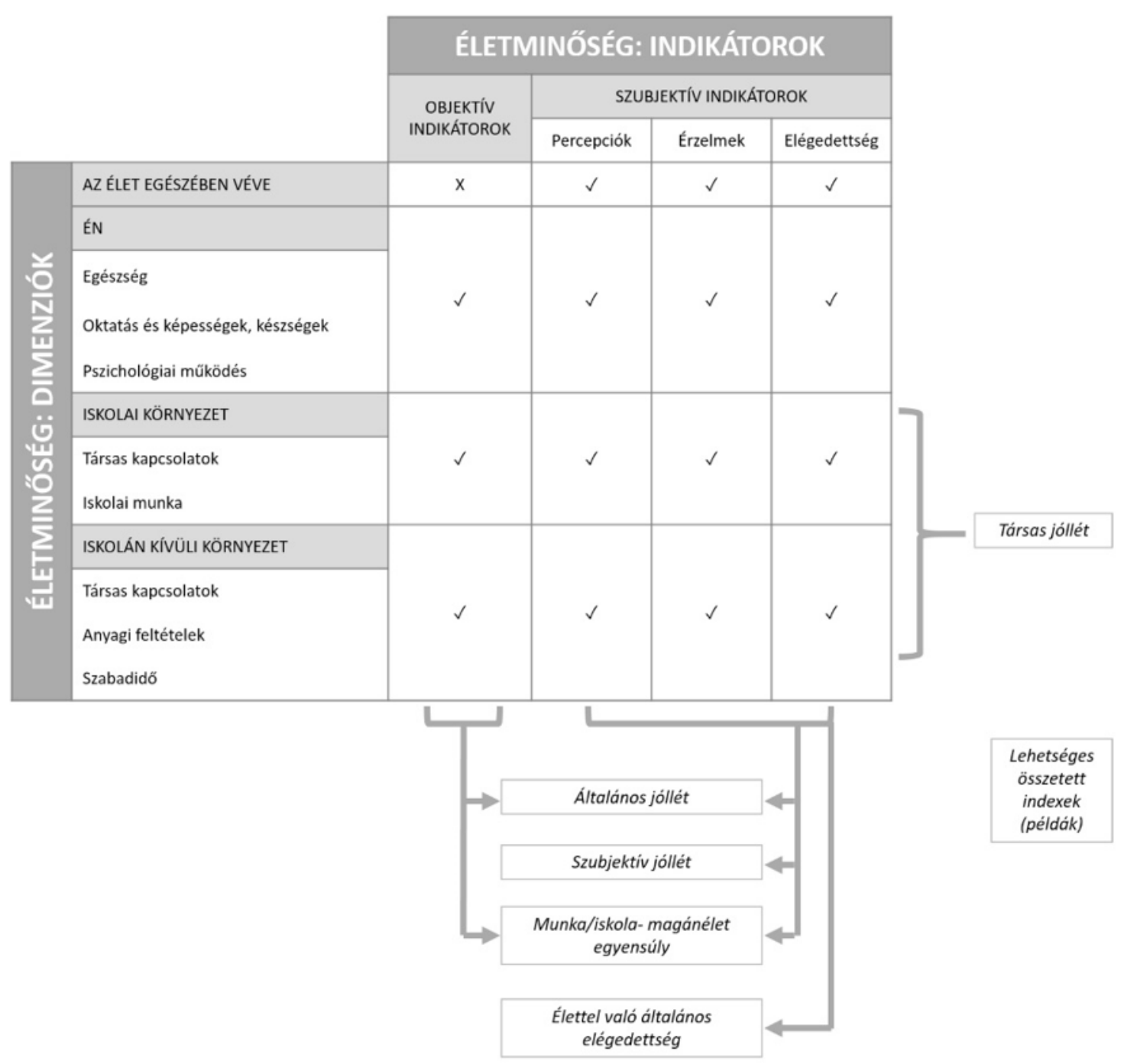

3. ábra: A PISA-vizsgálat jóllétkoncepciójának moduláris keretrendszere (saját szerkesztés OECD, 2019a, p. 258 alapján)

A PISA 2018-as adatfelvételében a tanulói jóllét négy indikátora került a vizsgálat fókuszába, amelyek az összes jóllétindikátornak csupán egy részét fedik le: (1) az élettel való elégedettség és az élet értelme, (2) a tanulók érzelmei, (3) az énhatékonyság és a kudarcfélelem, valamint (4) a fejlődés fókuszú szemléletmód (growth mindset). A vizsgált indikátorokat kiegészítették egyéb kapcsolódó területek, mint például az iskolai klímára (tanulói viselkedés, pedagógusok viselkedése és diákokhoz való viszonyulása, iskolai közösség) vagy a családi-háztartási és iskolai erőforrásokra vonatkozó kérdésblokkok (OECD, 2019b).

\section{A vizsgált nemzetközi kutatások jóllétdimenzióinak összevetése}

A továbbiakban az ISCWeB (2016-2019), a HBSC (2017/2018) és a PISA (2018) felmérések legutóbbi adatfelvételeinek a tanulói jóllét feltérképezését célzó dimenzióit, témaköreit vetjük össze, azok közös pontjaira fókuszálva. A PISA kapcsán a standard kérdőívben szereplő kérdések mellett a választható jóllétkérdőívben szereplő kérdéseket is számba vesszük. Elemzésünkben csak azokra a dimenziókra, témakörökre térünk ki, melyek 
a nemzetközi kutatások közül legalább kettőben szerepeltek. Így az alábbi dimenziókat, témaköröket vetjük össze: ${ }^{6}$

- élettel való általános elégedettség,

- érzelmi állapot,

- pszichológiai jóllét,

- családi élet,

- baráti kapcsolatok,

- iskolai élet (iskolatársakkal, tanárokkal való kapcsolat),

- egészségi állapot,

- szubjektív és objektív testkép.

Élettel való általános elégedettség

A jóllétvizsgálatok visszatérő területe az élettel való elégedettség, mely az élettel, annak minőségével kapcsolatos általános értékítéletet mutatja. A mérési gyakorlatban előfordul mind az egy itemmel való kérdezés - mely tömör és lényegre törő, ugyanakkor általános, szubjektív értelmezést lehetővé tévő kérdezési forma (Rees et al., 2013) -, mind a több item alkalmazásával történő kérdezés. Az élettel való elégedettség mindhárom vizs gált nemzetközi kutatásban megjelent, azonban az egyes vizsgálatok eltérőek az alkalmazott megközelítés, illetve kérdés vonatkozásában (lásd a Melléklet 1. táblázatát).

Az ISCWeB 3. hullámában az élettel való általános elégedettség a szubjektív jóllét kognitív komponense, melynek mérésére alkalmazták mind az egy-, mind a több-itemes kérdezési technikát: (1) az Overall Subjective Well-Being Scale (OLS) egy kérdés segítségével tárta fel az élettel való általános elégedettséget, (2) a Children's Worlds Subjective Well-Being Scale (CW-SWBS) - melynek kialakításához az ISCWeB kutatói a Huebner (1991) által kidolgozott koncepciót (Student Life Satisfaction Scale) vették alapul - pedig 6 itemmel mérte ugyanezt. A HBSC 2017/2018-as adatfelvételében az élettel való elégedettség a mentális jóllét, a PISA 2018-ban pedig a tanulói jóllét pszichológiai dimenziójának egyik összetevője. Az élettel való elégedettség mérésére mindkét kutatás az ún. Cantril-létrát ${ }^{7}$ (Cantril, 1965) alkalmazta.

\section{Érzelmi állapot}

A szubjektív jóllétkoncepciók általában nem csak az élet egészével, illetve annak egyes területeivel kapcsolatos kognitív komponenseket (elégedettség, percepció) foglalnak magukban, hanem affektív összetevőket is (Casas, 2011; OECD, 2019a). A tanulók érzelmi állapota mint affektív komponens az ISCWeB és a PISA kutatásban jelenik meg, míg a HBSC felmérése nem érintette ezt a területet (lásd a Melléklet 2. táblázatát).

Az ISCWeB kutatásban a szubjektív jóllét affektív összetevőinek mérésére szolgáló skála (Children's Worlds Positive and Negative Affects Scale, CW-PNAS) Diener (1984) megközelítésére, valamint Feldman-Barrett és Russell (1998) bipoláris pszichológiai modelljére épül. A skála a 10 és 12 éveseknél 6 kérdés segítségével 11 foko zaton méri a tanulók pozitiv (PAS) és negatív (NAS) érzelmi állapotát. A PISA 2018-as adatfelvételében a tanulók érzelmi állapota a tanulói jóllét pszichológiai dimenziójának egyik komponenseként jelent meg. A megélt érzelmek vizsgálatára vonatkozó kérdésfeltevés hasonló az ISCWeB kutatáséhoz, azonban különbség mutatkozik a felsorolt itemekben (azaz a megkérdezett érzelmi állapotok körében), valamint a skála kategóriákban (ISCWeB:

6. Az egyes dimenziókat összehasonlító táblázatokat a Melléklet tartalmazza.

7. A 11 fokú Cantril-létra legalsó foka, azaz a skála legkisebb, 0-s értéke az élettel való legkisebb, míg a legfelső foka, vagyis a legmagasabb, 10-es értéke az élettel való legnagyobb elégedettséget jelenti. 
11 fokozatú skála, PISA: négy kategória). További különbség, hogy míg az ISCWeB kutatás az elmúlt két hétre vonatkoztatva kérdez rá az érzelmekre, addig a PISA általánosságban. Ezen standard kérdésen felül a PISA vá lasztható jóllétkérdőive különböző szituációkra vonatkoztatva (például egyes tanórák, órák közötti szünetek, házi feladat készítés) is rákérdezett a tanulói érzelmekre (OECD, 2019b).

\section{Pszichológiai jóllét}

A jóllét pszichológiai aspektusa a személyes fejlődéssel, növekedéssel kapcsolatos pszichológiai jellemzőket foglalja magában (Kahneman, Diener \& Schwarz, 1999). Az érzelmi állapot dimenzióhoz hasonlóan ez a dimenzió szintén csak az ISCWeB és a PISA-vizsgálatban jelent meg, a HBSC adatfelvételében azonban nem (lásd a Melléklet 3. táblázatát).

Az ISCWeB-kutatásban a pszichológiai jóllét az eudaimonikus felfogáshoz kötődik, a jóllétet az elégedettségnél, a boldogságnál többnek tartja, inkább a kiteljesedéssel azonosítja. Az ISCWeB-ben a 12 éves tanulók pszichológiai jóllétét meghatározó 6 itemes mérőeszköz (Children's Worlds Psychological Subjective Well-Being Scale, CW-PSWBS) alapját Ryff (1989) többtényezős modellje adja. A PISA jóllét-koncepciójában a pszichológiai jóllét ernyőfogalom, mely magában foglalja a diák saját életével, iskolai elköteleződésével, jövőbeli céljaival és ambícióval kapcsolatos értékelését és nézeteit (Borgonovi \& Pál, 2016; OCED, 2019b). A PISA 2018-as mérésében tematikailag ide sorolható a korábban már tárgyalt élettel való általános elégedettség és tanulói érzelmek mellett néhány pszichológiai (tanulói énhatékonyság és kudarctól való félelem, az élet értelme) és kognitiv témakör (fejlődésfókuszú szemléletmóddal való rendelkezés, tanulás szerepe, tanulmányi célok, teljesítményorientáció). Így a két nemzetközi kutatás megfeleltetése ez esetben lényegesen nehezebb, mint az előzőekben tárgyalt két dimenziónál. Ráadásul itt is elmondható, hogy míg a ISCWeB 11 fokozatú skálán mért, addig a PISA négy kategóriás válaszlehetőséget adott meg.

\section{Családi élet}

A gyermekek jóllétének vizsgálatakor figyelembe kell venni mindazon színtereket, csoportokat, melyek meghatározóak a gyermekek számára. Az egyik legfontosabb ilyen színtér és egyben társas közeg a család, mely terület mindhárom vizsgált kutatásban megjelenik (lásd a Melléklet 4. táblázatát).

Az ISCWeB kutatás elméleti keretében az élettel való általános elégedettség mellett a szubjektív jóllét kognitív összetevője az élet különböző területeivel kapcsolatos, ún. területspecifikus elégedettség is. Az egyik ilyen vizsgált terület a család. Ennek kapcsán mérték a családi élet egyes aspektusaival (gondoskodás, támogatás, közös időtöltés, biztonság, döntéshozatal) kapcsolatos tanulói nézeteket (5 kategóriás válaszlehetőségekkel), valamint a családtagokkal való elégedettséget ${ }^{8}$ is (8 éveseknél 1-5 skála, 10 és 12 éveseknél 0-10 skála). A HBSC-kutatásban a családi támogatás mint a társas jóllét egyik indikátora jelent meg. A kérdőívtételek a család érzelmi támogatására, döntéshozatalban és problémák megoldásában nyújtott segítségnyújtására vonatkoztak, így többé-kevésbé megfeleltethetők az ISCWeB-ben szereplő itemeknek. Különbség ugyanakkor, hogy a HBSC válaszlehetőségként az ISCWeB-től eltérően 7 fokozatú skálát alkalmazott. A tanulói jóllét társas dimenziójához kapcsolódóan a PISA standard tanulói kérdőivében is szerepeltek családi támogatásra vonatkozó itemek, azonban itt nem az érzelmi, hanem az iskolai tanulmányokra vonatkozó szülői támogatás volt a fókusz-

8. A családdal való elégedettség a területspecifikus elégedettség összegző skálájának (Children's Worlds Domain Based Subjective Well-Being Scale, CW-DBSWBS) egyik iteme. A skála összesen 5 területtel való elégedettséget összegez: (1) család, (2) barátok, (3) iskolásnak lenni, (4) lakóhely környéke, (5) külső megjelenés. A skála kidolgozásához Seligson, Huebner és Valois (2003) mérőeszközét (Brief Multidimensional Student Life Satisfaction Scale) vették alapul. 
ban. A családi kapcsolatokról alkotott percepció, a szülői támogatás érzelmi aspektusa, a családdal való elégedettség vizsgálatára a PISA választható jóllétkérdőive nyújtott lehetőséget. Mint általában, e tématerület esetében is négy kategóriás válaszlehetőség közül választhattak a PISA-felmérésben részt vevő tanulók.

\section{Baráti kapcsolatok}

A baráti kapcsolatok kisgyermekkortól kezdve, az iskolába lépést követően egyre nagyobb szerepet kapnak a gyermekek életében, serdülőkorban pedig a barátok már referenciaként segítik az identitás alakulását, az énkép fejlődését. A szociális fejlődésre gyakorolt hatás mellett a baráti kapcsolatok a valahova tartozás, kötódés érzését is erősítik, és hozzájárulnak a gyermekek boldogságához, jóllétéhez (Borgonovi \& Pál, 2016). A baráti kapcsolatokra vonatkozó kérdésblokk mindhárom vizsgált felmérésben megjelent (lásd a Melléklet 5. táblázatát).

Az ISCWeB kutatási keretében a barátokkal való elégedettség (8 éveseknél 1-5 skála, 10 és 12 éveseknél 010 skála) a területspecifikus elégedettség, azaz a szubjektív jóllét kognitív komponensét mérő skála (Children's Worlds Domain Based Subjective Well-Being Scale, CW-DBSWBS) egyik eleme. A felmérésben a barátok jelenlétére, viszonyulására és támogatására vonatkozó kérdések is szerepeltek ( 5 kategóriás válaszlehetőséggel). $A$ HBSC-kutatásban a kortárstámogatás a társas jóllét egyik indikátoraként jelent meg. A kérdőívtételek tartalom szempontjából hasonlóak az ISCWeB-ben feltett kérdésekhez: azt vizsgálják, hogy a tanulók mennyiben érzik barátaik támogatását, mennyiben számíthatnak segítségükre és oszthatják meg örömeiket és nehézségeiket velük. Fő különbségként itt is a válaszkategóriák száma jelenik meg, hiszen a HBSC-ben 7 fokozatú skálán válaszolhattak a megkérdezett tanulók. A PISA 2018-as adatfelvételében csak a választható tanulói jóllétkérdőív tartalmazott ehhez kapcsolódó itemeket, mint például közeli barátok száma, barátokkal való elégedettség (4 kate góriás válaszlehetőséggel), kommunikáció.

\section{Iskolai élet (iskolatársakkal, tanárokkal való kapcsolat)}

A gyermekek otthonuk mellett az iskolában, a tantermekben töltik idejük nagy részét osztálytársak, pedagógusok és más iskolai dolgozók körében. Mindaz a tapasztalat, élmény, ami e társas közegben a tanulókat éri, fon tos jóllétük, boldogságuk, másokhoz való kapcsolódásuk és jövőbeli terveik megértése szempontjából (Borgonovi \& Pál, 2016). Az iskolai élettel kapcsolatosan mindhárom kutatás több témakörben gyújtött adato kat a tanulóktól. Ezek hasonlóságait, metszeteit keresve három nagyobb egység rajzolódik ki: (1) az iskolával, iskolai élettel való elégedettség (lásd a Melléklet 6. táblázatát), (2) az iskolatársakkal való kapcsolat, ideértve a(z) (online) kortársbántalmazás (bullying) témakörét is (lásd a Melléklet 7. táblázatát) és (3) a tanárokkal való kapcsolat (lásd a Melléklet 8. táblázatát).

A felmérésekben az iskola, az iskolai élet számos aspektusa megjelent, hozzátéve, hogy az egyes kutatások ban némiképp máshova helyeződik a hangsúly. Az ISCWeB-kutatás és a PISA választható jóllétkérdőíve például az iskolai élettel és az iskolában tanultakkal való elégedettségre tér ki, míg a HBSC-vizsgálat az iskolához fűződő érzelmekre és az iskolai nyomásra. Válaszlehetőségként az ISCWeB 5 kategóriás vagy 0-10 fokozatú skálát, a HBSC és a PISA viszont 4 kategóriás skálát használt.

Mindhárom vizsgálatban megjelennek az osztálytársakkal való elégedettséget (egy vagy több itemmel) mérő kérdések, illetve az arra vonatkozó kérdések, hogy az adott tanuló mennyire része az iskolai- és osztályközösségnek, mennyire támogató, illetve konfliktusokkal terhelt az iskolai, illetve osztálylégkör, az iskolatársakkal, osztálytársakkal való kapcsolat (a többi tématerülethez hasonlóan itt is eltérés mutatkozik a válaszok megadásánál alkalmazott skálák fokozataiban). Az iskola- és osztálytársak kapcsán mindhárom felmérésben markánsan 
megjelenik az iskolában történő kortársbántalmazás kérdésköre (áldozatként és bántalmazóként egyaránt), a HBSC ezen felül kitér az online térben történő bántalmazásra (cyberbullying) is.

A tanulók pedagógusokkal való kapcsolata az ISCWeB kutatási keretében a szubjektív jóllét egyik kognitív komponense, a területspecifikus elégedettség körébe tartozik. Mindazonáltal, az egyes korcsoportoknak szánt kérdőívváltozatokban csak a pedagógusok gondoskodó, támogató attitűdjéről gyűjtöttek adatot (5 kategóriás válaszlehetőséggel), a tanárokkal való elégedettségről nem. A HBSC-kérdőiv a tanári támogatásra, azaz a tanárok részéról tapasztalható elfogadás, gondoskodás és bizalom mértékére kérdezett rá (5 fokozatú skálán). A PISA 2018-as standard tanulói kérdőivében is szerepeltek a tanári támogatásra és a pedagógiai gyakorlatra vonatkozó itemek (általában 4 kategóriás válaszlehetőségekkel). Ezek egy része funkcionálisan megfeleltethető az ISCWeB-ben szereplő állításoknak (például a tanár figyelmére és megértő attitúdjére vonatkozó állítások), ugyanakkor - hasonlóan a szülői támogatás témaköréhez - a segítségnyújtásra vonatkozó itemek itt sem a támogatás érzelmi aspektusára, hanem inkább a tanulástámogatásra fókuszálnak. A tanár-diák kapcsolattal való elégedettségre és a kapcsolat bizalmas voltára vonatkozó további kérdések a PISA választható jóllétkérdőívében szerepeltek.

\section{Egészségi állapot}

A gyermekek fizikai, egészségi állapotának - és annak szubjektív megítélésének - is meghatározó szerepe van a jobb iskolai teljesítmény, a szociális sikeresség és az érzelmi stabilitás elérésében (Borgonovi \& Pál, 2016). Erre vonatkozóan részben hasonló, részben megegyező kérdések szerepeltek mindhárom nemzetközi kutatásban, bár a PISA esetében csak a választható jóllétkérdőív tartalmaz egészséggel kapcsolatos kérdéseket, a standard mérőeszköz nem (lásd a Melléklet 9. táblázatát). Természetesen, mivel a HBSC-kutatás fókuszában az egészségmagatartás vizsgálata áll, jóval részletesebben és átfogóbban tárgyalja ezt a kérdéskört, mint az ISC WeB vagy a PISA (ugyanakkor jelen tanulmányban csak a közös pontokra térünk ki).

Az egészség kapcsán az ISCWeB az egészséggel való elégedettségre (8 éveseknél 1-5 skála, 10 és 12 éveseknél 0-10 skála), a HBSC a szubjektív egészségi állapotra kérdezett rá (4 kategóriás válaszlehetőséggel), míg a PISA válaszható jóllétkérdőíve mindkét kérdést tartalmazta (4 kategóriás válaszlehetőségekkel). Ezen felül mindhárom felmérés vizsgálta a különböző egészségügyi panaszok, tünetek (fej-, gyomor-, hátfájás, alvási nehézség stb.) elmúlt 6 hónapban előforduló gyakoriságát is.

\section{Szubjektív és objektív testkép}

A testkép az énkép egyik fontos eleme, mely a saját test szubjektiv értékelését és a hozzá kapcsolódó érzelmi viszonyulást is magában foglalja. A testkép, a testtudatosság a gyermekkorból a serdülőkorba lépve egyre fontosabb szerepet kap az önértékelésben (Németh \& Költő, 2016), így a jóllét elválaszthatatlan része, és összefüggést mutat annak külön aspektusaival, például a pszichológiai és társas jólléttel (Csabai, 2019). A testkép vizsgálata mindhárom kutatásban megjelent, bár a kérdésfeltevés tekintetében eltértek a vizsgálatok.

Az ISCWeB csak a szubjektív testképre vonatkozó kérdést tartalmazott: a saját kinézettel való elégedettség (8 éveseknél 1-5 skála, 10 és 12 éveseknél 0-10 skála) a területspecifikus elégedettség, így a szubjektív jóllét kognitív komponensének (és egyben a CW-DBSWBS skála) részeként jelent meg a kutatásban. A HBSC vizsgálta mind az objektív, mind a szubjektív testképet: egyfelől a súly és a magasság megadását kérte a részt vevő tanulóktól, másfelől saját kinézetüket (tápláltsági állapotukat) is jellemezniük kellett (5 kategóriás válaszlehetőséggel). A PISA 2018-as adatfelvételében csak a választható jóllétkérdőívben szerepeltek (a HBSC-vizsgálatához hasonlóan) objektív és szubjektív testképre vonatkozó kérdések. Így kérdések irányultak a válaszadó tanuló sú- 
lyára és magasságára (objektív testkép), valamint a saját test és megjelenés szubjektív megítélésére (4 kategóriás válaszlehetőséggel).

\section{Összegző megállapítások}

Tanulmányunkban három nemzetközi tanulói felmérés, az ISCWeB, a HBSC és a PISA jóllétkoncepcióját, valamint a felmérések legutóbbi adatfelvételeiben vizsgált tanulói jóllétdimenziókat hasonlítottuk össze. Elemzésünkben csak azon dimenziókat vetettük össze, melyek a nemzetközi kutatások közül legalább kettőben szerepeltek. Így vizsgáltuk az élettel való általános elégedettség, az érzelmi állapot, a pszichológiai jóllét, a családi élet, a baráti kapcsolatok, az iskolai élet (iskolatársakkal, tanárokkal való kapcsolat), az egészségi állapot, vala mint a szubjektív és objektív testkép területeit. A vizsgált nyolc dimenzió közül hat mind a három felmérésben megjelent, kettő (érzelmi állapot, pszichológiai jóllét) viszont csak az ISCWeB- és a PISA-kutatásban.

A tanulói jóllét vizsgálatát mindhárom felmérés többdimenziós keretbe ágyazza, ami magában foglalja a fizikai, kognitív, pszichológiai, társas és egészséggel kapcsolatos dimenziókat, területeket. Itt azonban fontos megjegyezni, hogy az ISCWeB-kutatás kifejezetten a gyermekek szubjektív jóllétére fókuszál, míg a HBSC az általános iskolai tanulók egészségi állapotát és egészségmagatartását vizsgálja, a PISA pedig elsősorban a tanulók is kolai eredményességét, vagyis utóbbi kettő felmérésben a szubjektív jóllétre irányuló kérdések kiegészítő jellegúek (a PISA esetében például a legtöbb jóllétre vonatkozó kérdés nem a standard, hanem a választható tanulói jóllétkérdőívben szerepel). Ez azt is jelenti, hogy a tanulók jóllétére vonatkozó kérdések kontextusa is eltérő ezekben a felmérésekben. A három kutatásban vizsgált iskolai tanulók életkora sem pontosan azonos: az ISCWeB 8, 10 és 12 éves, a HBSC 11, 13 és 15 éves, míg a PISA 15 éves tanulókat vizsgál.

Összehasonlításunk eredménye azt mutatja, hogy mindhárom vizsgált nemzetközi adatfelvételben szerepelnek jólléthez köthető kérdések, bár a feltett kérdések nem minden esetben feleltethetők meg teljesen egymás nak a vizsgált felmérésekben. Az egyes dimenziókban megjelenő kérdések egy része megközelítőleg azonos, másik része kapcsán viszont inkább csak tartalmi, funkcionális megfeleltetésről lehet beszélni. Általában különbség mutatkozik az egyes dimenziókhoz tartozó kérdések, illetve itemek számában, valamint a megadott válaszlehetőségek kategóriáiban (skálák fokozatában). Az ISCWeB elsősorban 5 kategóriás vagy 11 fokozatú skálát alkalmazott, míg a PISA általában 4 kategóriás válaszlehetőségeket adott meg. A HBSC-ben szélesebb válaszkészlet jelenik meg, hiszen szerepelnek benne 4 és 5 kategóriás válaszlehetőségek, illetve 7 és 11 fokozatú skálák is.

Módszertani szempontból fontos megemlíteni azt is, hogy egy felmérés milyen időintervallumra vonatkoztatva kérdez rá bizonyos jelenségek előfordulására (például érzelmi állapot, bántalmazás, egészségügyi panaszok előfordulása). Ennek kapcsán megállapítható, hogy a vizsgált felmérések a legtöbb esetben általánosságban kérdeznek rá a jelenségekre, ugyanakkor bizonyos esetekben jelentős különbség van a viszonyítási pontokban (például bántalmazás előfordulása esetén az ISCWeB az elmúlt hónapra, a HBSC az elmúlt néhány hónapra, a PISA az elmúlt 12 hónapra/idei tanévre kérdezett rá).

Vizsgálatunk alapvető korlátja, hogy három nemzetközi felmérésre, azok összevetésére szúkíti a tanulói jóllét vizsgálatát, s az összehasonlítás során több esetben is csak a szerzők szakmai döntésén alapuló tartalmi, funkcionális megfeleltetésre volt lehetőség. Ugyanakkor a későbbiekben ennek fényében is érdemesnek tartjuk a három vizsgált nemzetközi felmérés hasonlóságait és különbségeit figyelembe véve ezen felmérések eredményei alapján megvizsgálni a tanulók jóllétének jellegzetességeit, különösen fókuszálva a magyar eredményekre. Egy ilyen elemzés alapján több aspektusból és komplexebben vizsgálható a jóllét, és az, hogy e tekintetben hol helyezkednek el a magyar tanulók a nemzetközi térben. 


\section{Köszönetnyilvánítás}

Széll Krisztián a tanulmány megírása alatt ÚNKP posztdoktori kutatói ösztöndíjban részesült. A tanulmány az Innovációs és Technológiai Minisztérium ÚNKP-20-4 kódszámú Új Nemzeti Kiválóság Programjának a Nemzeti Kutatási, Fejlesztési és Innovációs Alapból finanszírozott szakmai támogatásával készült.

Emellett a kutatást az NKFIH NN 125715. számú, Gyermekek az iskolában: Jóllét és azon túl címú projektje támogatta, kutatásvezető: Róbert Péter. A kutatás megalapozása idején, 2019 októbere és 2020 júniusa között, Róbert Péter a CEU IAS Senior Core Fellow-ja volt.

\section{Irodalom}

1. Awartani, M., Whitman, C. V., \& Gordon, J. (2008). Developing Instruments to Capture Young People's Perceptions of How School as a Learning Environment Affects of Their Well-Being. European Journal of Education, 43(1), 51-70. Retrieved from https://doi.org/10.1111/j.1465-3435.2007.00337.x

2. Borgonovi, F. \& Pál, J. (2016). A framework for the analysis of student well-being in the PISA 2015 study: Being 15 in 2015. OECD Education Working Papers, No. 140. Paris: OECD Publishing. Retrieved from http://dx.doi.org/10.1787/5jlpszwghvvb-en.

3. Bourke, L. \& Geldens, P. (2007). What Does Wellbeing Mean?: Perspectives of Wellbeing among Young People \& Youth Workers in Rural Victoria. Youth Studies Australia, 26(1), 41-49. Retrieved from https://search.informit.org/doi/10.3316/ielapa.365950962724213.

4. Cantril, H. (1965). The Pattern of Human Concern. New Jersey: Rutgers University Press.

5. Casas, F. (2011). Subjective Social Indicators and Child and Adolescent Well-Being. Child Indicators Research, 4(4), 555-575. Retrieved from https://doi.org/10.1007/s12187-010-9093-z

6. Casas, F. (2019). Introduction to the Special Section on Children's Subjective Well-Being. Child Development, 90(2), 333-343. Retrieved from https://doi.org/10.1111/cdev.13129

7. Cho, E. \& Yu, F. (2020). A Review of Measurement Tools for Child Wellbeing. Children and Youth Services Review, 119. DOI: 10.1016/j.childyouth.2020.105576

8. Csabai, M. (2019). Az önelfogadás kihívásaitól a testpozitív mozgalmakig - a pozitív pszichológia testképei. Magyar Pszichológiai Szemle, 74(3), 361-373. DOI: 10.1556/0016.2019.74.3.6

9. Deci, E. L. \& Ryan, R. M. (2008). Hedonia, Eudaimonia, and Well-Being: An Introduction. Journal of Happiness Studies, 9(1), 1-11. Retrieved from https://doi.org/10.1007/s10902-006-9018-1

10. Diener, E. (1984). Subjective Well-Being. Psychological Bulletin, 95(3), 542-575. Retrieved from https://doi.org/10.1037/0033-2909.95.3.542

11. Feldman-Barrett, L. \& Russell, J. A. (1998). Independence and Bipolarity in the Structure of Current Affect. Journal of Personality and Social Psychology, 74(4), 967-984. Retrieved from https://doi.org/10.1037/0022-3514.74.4.967

12. Hamvai, Cs. \& Pikó, B. (2008). Pozitív pszichológiai szempontok az iskola világában: a pozitív pedagógia kihívásai. Magyar Pedagógia, 108(1), 71-88.

13. Huebner, E. S. (1991). Further Validation of the Students' Life Satisfaction Scale: The Independence of Satisfaction and Affect Ratings. Journal of Psychoeducational Assessment, 9(4),363-368. Retrieved from https://doi.org/10.1177/073428299100900408

14. Huppert, F. A. (2014). The state of well-being science: Concepts, measures, interventions and policies. In F. A. Huppert, \& C. Cooper (Eds.), Interventions and policies to enhance well-being (pp. 1-49). Oxford: Wiley-Blackwell.

15. Inchley, J., Currie, D., Cosma, A., \& Samdal, O. (Eds., 2018). Health Behaviour in School-aged Children (HBSC) study protocol: background, methodology and mandatory items for the 2017/18 survey. St Andrews: Child and Adolescent Health Research Unit. 
16. Inchley, J., Currie, D., Budisavljevic, S., Torsheim, T., Jåstad, A., Cosma, A., Kelly, C., \& Arnarsson Á. M. (Eds., 2020). Spotlight on Adolescent Health and Well-Being. Findings from the 2017/2018 Health Behaviour in School-Aged Children (HBSC) Survey in Europe and Canada. International Report. Volume 1. Key findings. Copenhagen: WHO Regional Office for Europe.

17. Kahneman, D., Diener, E., \& Schwarz, N. (Eds., 1999). Well-Being: The Foundations of Hedonic Psychology. New York: Russell Sage Foundation.

18. Konu, A. I., Lintonen, T. P., \& Rimpelä, M. K. (2002). Factors associated with school- children's general sub-jective well-being. Health Education Research, 17(2), 155-165. DOI: 10.1093/her/17.2.155

19. Nagy, K. (2018). Az iskolai jóllét dimenzióinak empirikus vizsgálata általános iskolás tanulók körében. In G. Keresztes \& Cs. Szabó (Eds.), Tavaszi Szél - Spring Wind 2018, III. kötet (pp. 366-376). Budapest: Doktoranduszok Országos Szövetsége.

20. Nagy, K., Gál Z., Jámbori, Sz., Kasik L. \& Fejes, J. B. (2019). A tanulói jóllét és az önértékelés jellemzőinek feltárása középiskolások és egyetemisták körében. Iskolakultúra, 29(6), 3-17. DOI: 10.14232/ISKKULT.2019.6.3

21. Németh, Á. \& Költő, A. (Eds., 2016). Egészség és Egészségmagatartás Iskoláskorban 2014. Az „Iskoláskorú gyermekek egészségmagatartása" elnevezésü, az Egészségügyi Világszervezettel együttmüködésben zajló nemzetközi kutatás 2014. évi felméréséről készült nemzeti jelentés. Budapest: Nemzeti Egészségfejlesztési Intézet.

22. Németh, Á. \& Várnai, D. (Eds., 2019). Kamaszéletmód Magyarországon. Budapest: L'Harmattan Kiadó.

23. Noble, T., \& McGrath, H. (2008). Positive educational practices framework: A tool for facilitating the work of educational psychologist in promoting pupil wellbeing. Educational and Child Psychology, 25(2), 119-134.

24. OECD (2019a). PISA 2018 Assessment and Analytical Framework. Paris: OECD Publishing. Retrieved from https://doi.org/10.1787/b25efab8-en.

25. OECD (2019b). PISA 2018 Results (Volume III): What School Life Means for Students' Lives. Paris: OECD Publishing. Retrieved from https://doi.org/10.1787/acd78851-en

26. Oktatási Hivatal (2019). PISA2018. Összefoglaló jelentés. Budapest: Oktatási Hivatal.

27. Oláh, A. \& Kapitány-Fövény, M. (2012). A Pozitív Pszichológia tíz éve. Magyar Pszichológiai Szemle, 67(1), 19-45. DOI: 10.1556/MPSzle.67.2012.1.3

28. Örkényi, Á. \& Koszonits, R. (2004). Akiknek sem otthon, sem az iskolában nem jó. Iskolakultúra, 14(8), 43-55.

29. Pollard, E. L. \& Lee, P. D. (2003). Child wellbeing: A systematic review of the literature. Social Indicators Research, 61(1), 59-78. Retrieved from https://doi.org/10.1023/A:1021284215801

30. Rees, G., Goswami, H., Pople, L., Bradshaw, J., Keung, A., \& Main, G. (2013). The Good Childhood Report 2013. London: The Children's Society.

31. Ryan, R. M. \& Deci, E. L. (2001). On Happiness and Human Potentials: A Review of Research on Hedonic and Eudaimonic Well-Being. Annual Review of Psychology, 52(1), 141-166. DOI: 10.1146/annurev.psych.52.1.141

32. Ryff, C. D. (1989). Happiness is everything, or is it? Explorations on the meaning of psychological wellbeing. Journal of Personality and Social Psychology, 57(6), 1069-1081. Retrieved from https://doi.org/10.1037/0022-3514.57.6.1069

33. Seligman M. E. P., Ernst, R. M., Gillham, J., Reivicha, K., \& Linkins, M. (2009). Positive educati-on: positive psychology and classroom interventions. Oxford Review of Education, 35(3), 293-311.

34. Seligman, M. E. P. \& Adler, A. (2019). Positive Education. In J. F. Helliwell, R. Layard, \& J. Sachs (Eds.), Global Happiness and Wellbeing. Policy Report 2019 (pp. 53-71). New York: Sustainable Development Solutions Network. 
35. Seligson, J. L., Huebner, E. S., \& Valois, R. F. (2003). Preliminary Validation of the Brief Multidimensional Students' Life Satisfaction Scale (BMSLSS). Social Indicators Research, 61, 121-145. Retrieved from https://doi.org/10.1023/A:1021326822957

36. Soutter, A. K., O'Steen, B., \& Gilmore, A. (2014). The student well-being model: a conceptual framework for the development of student wellbeing indicators. International Journal of Adolescence and Youth, 19(4), 496-520. Retrieved from https://doi.org/10.1080/02673843.2012.754362

37. Szabó, D. F. (2016). A rövidített WHO jól-lét kérdőív gyermekek körében való alkalmazásának lehetőségei. Iskolakultúra, 26(11), 113-118.

38. Veenhoven, R. (2007). Subjective measures of well-being. In M. McGillivray (Ed.). Human Well-Being: Concept and Measurement (pp. 214-239). Basingstoke: Palgrave Macmillan.

39. Vieno, A., Santinello, M., Galbiati, E., \& Mirandola, M. (2004). School climate and well being in early adolescence: A comprehensive model. European Journal of School Psychology, 2(1-2), 219-238.

40. Williams, P. G., Holmbeck, G. N., \& Greenley, N. (2002). Adolescent health psychology. Journal of Consulting and Clinical Psychology, 70(3), 828-842. 


\section{Melléklet}

ISCWEB 2016-2019

Szubjektív jóllét: kognitív
komponens => élettel való
elégedettség

\section{HBSC 2017/2018}

\section{PISA 2018}

\section{Dimenzió}

Egészségmagatartás: mentális jóllét => élettel való általános elégedettség

\section{Alkalmazott kérdés(ek)}

Itt van elötted egy létra. A létra teteje (10. fokozat) a lehető legjobb életet jelöli, a létra alja (0. fokozat) a lehető legrosszabb életet jelöli. Gondolj magadra, és jelöld be, hol állsz most a létrán!
Tanulói jóllét: pszichológiai dimenzió => élettel való általános elégedettség

Az alábbi kérdés arra vonatkozik, hogy mennyire vagy elégedett $a z$ életeddel egy 0-tól 10-ig terjedő skálán. A nulla azt jelenti, hogy „egyáltalán nem” vagy elégedett, a 10 pedig azt, hogy "tökéletesen elégedett” vagy. Összességében mennyire vagy elégedett $a z$ életeddel mostanában? 10 egyáltalán nem, 10 - tökéletesen)

Mennyire értesz egyet a következőkkel? (1-5 skála a 8 éveseknél, 0-10 skála a 10-12 éveseknél) (CW-SWBS)

- Élvezem az életemet.

- Jól megy az életem.

- Jó életem van.

- Szuper dolgok történnek az életemben.

- Szeretem az életemet.

- Örülök az életemnek. 


\section{Dimenzió}

Szubjektív jóllét: affektív komponens => a tanulók Tanulói jóllét: pszichológiai dimenzió => a tanulók pozitiv és negatív érzelmei pozitiv és negatív érzelmei

\section{Alkalmazott kérdés(ek)}

A következőkben különböző érzéseket sorolunk fel. Kérjük, olvasd el és jelöld meg mindegyiknél, hogy mennyire érezted magad ilyennek az elmúlt két hétben! ("soha", "néha", "gyakran", "mindig" a 8 éveseknél és csak a vidám és a szomorú érzelmekkel kapcsolatban, 0-10 skála a 10 és 12 éveseknél)

- Vidám (PAS)

- Szomorú (NAS)

- Nyugodt (PAS)

- Nyugtalan (NAS)

- Energiával, erővel teli (PAS)

- Unatkozó (NAS)
Gondolj arra, ahogy általában érzed magadat! Milyen gyakran szoktad érezni az alábbiakat? („soha”, „nagyon ritkán”, „néhány alkalommal”, „mindig”)

- Boldog vagyok

- Meg vagyok rémülve

- Tele vagyok energiával

- Nagyon lehangolt vagyok

- Büszke vagyok

- Tartok valamitől

- Jókedvú vagyok

- Szomorú vagyok

- Eleven és vidám vagyok

[Választható kérdőív] Milyen mértékben érezted az alábbiakat (1) a legutóbbi matematika-órádon? (2) a legutóbbi magyar nyelv- és irodalomórádon? (3) mikor legutóbb házi feladatot készítettél/tanultál („egyáltalán nem”, „egy kicsit”, „eléggé”, ,teljes mértékben")

- Unatkoztam

- Kihívást jelentett

- Ideges vagy feszült voltam

- Motivált vagy lelkes voltam

[Választható kérdőív] Milyen mértékben érezted az alábbiakat (1) a legutóbbi órák közötti szünetben? (2) mikor legutóbb otthonodon kívül időt töltöttél a barátaiddal? („egyáltalán nem”, „egy kicsit”, „eléggé”, „teljes mértékben”)

- Boldog voltam

- Magányos voltam

- Ideges vagy feszült voltam

- Tele voltam energiával

2. táblázat: Érzelmi állapot mérése a vizsgált kutatásokban 


\section{Dimenzió}

\begin{tabular}{|c|c|}
\hline \multirow{6}{*}{ Pszichológiai jóllét } & $\begin{array}{l}\text { (1) Tanulói jóllét: pszichológiai dimenzió => tanulói } \\
\text { énhatékonyság és kurdarctól való félelem }\end{array}$ \\
\hline & $\begin{array}{c}\text { (2) Tanulói jóllét: pszichológiai dimenzió => az élet } \\
\text { értelme }\end{array}$ \\
\hline & $\begin{array}{l}\text { (3) Tanulói jóllét: kognitív dimenzió => } \\
\text { fejlődésfókuszú szemléletmód (fejlődésfókuszú } \\
\text { szemléletmóddal való rendelkezés) }\end{array}$ \\
\hline & $\begin{array}{l}\text { (4) Tanulói jóllét: kognitív dimenzió => } \\
\text { fejlődésfókuszú szemléletmód (a tanulás szerepe) }\end{array}$ \\
\hline & $\begin{array}{l}\text { (5) Tanulói jóllét: kognitív dimenzió => } \\
\text { fejlődésfókuszú szemléletmód (tanulási célok) }\end{array}$ \\
\hline & $\begin{array}{l}\text { (6) Tanulói jóllét: kognitív dimenzió => } \\
\text { fejlődésfókuszú szemléletmód } \\
\text { (teljesítménymotiváció) }\end{array}$ \\
\hline
\end{tabular}

\section{Alkalmazott kérdés(ek)}

Kérjük, jelöld meg, mennyire értesz egyet általában a következőkkel! (0-10 skála; csak a 12 éveseknél) (CWPSWBS)

- Szeretem magam olyannak, amilyen vagyok.

- Jól boldogulok a napi feladataimmal.

- Az emberek általában barátságosak velem.

- Van elég választási lehetőségem, hogy hogyan töltsem el az időmet.

- Úgy érzem, mostanában sokat tanulok.

- Úgy érzem, jól fog alakulni a jövőm.
(1) Mennyire értesz egyet az alábbi állításokkal? („egyáltalán nem értek egyet”, „nem értek egyet”, „egyetértek”, „teljesen egyetértek”)

- Általában boldogulok így vagy úgy.

- Büszke vagyok arra, ha megvalósítottam valamit.

- Úgy érzem, több dolgot is tudok csinálni egy időben.

- $\mathrm{Az}$, hogy hiszek magamban, átsegít a nehéz időszakokon.

- Ha nehéz helyzetbe kerülök, általában találok kiutat belöle.

- Ha nem sikerül valami, aggódom, hogy mások mit gondolnak rólam.

- Ha nem sikerül valami, félek, hogy talán nem vagyok elég tehetséges.

- Ha nem sikerül valami, kételkedni kezdek a jövőbeli terveimmel kapcsolatban.

(2) Mennyire értesz egyet az alábbi állításokkal? („egyáltalán nem értek egyet”, „nem értek egyet”, „egyetértek”, „teljesen egyetértek”)

- Világos céljaim vannak az életben.

- Megnyugtató módon rátaláltam az élet értelmére.

- Pontosan tudom, hogy mi az életem értelme.

(3) Mennyire értesz egyet az alábbi állitásokkal? („egyáltalán nem értek egyet”, „nem értek egyet”, "egyetértek”, „teljesen egyetértek”

- Az intelligenciád egy olyan tulajdonságod, amit 


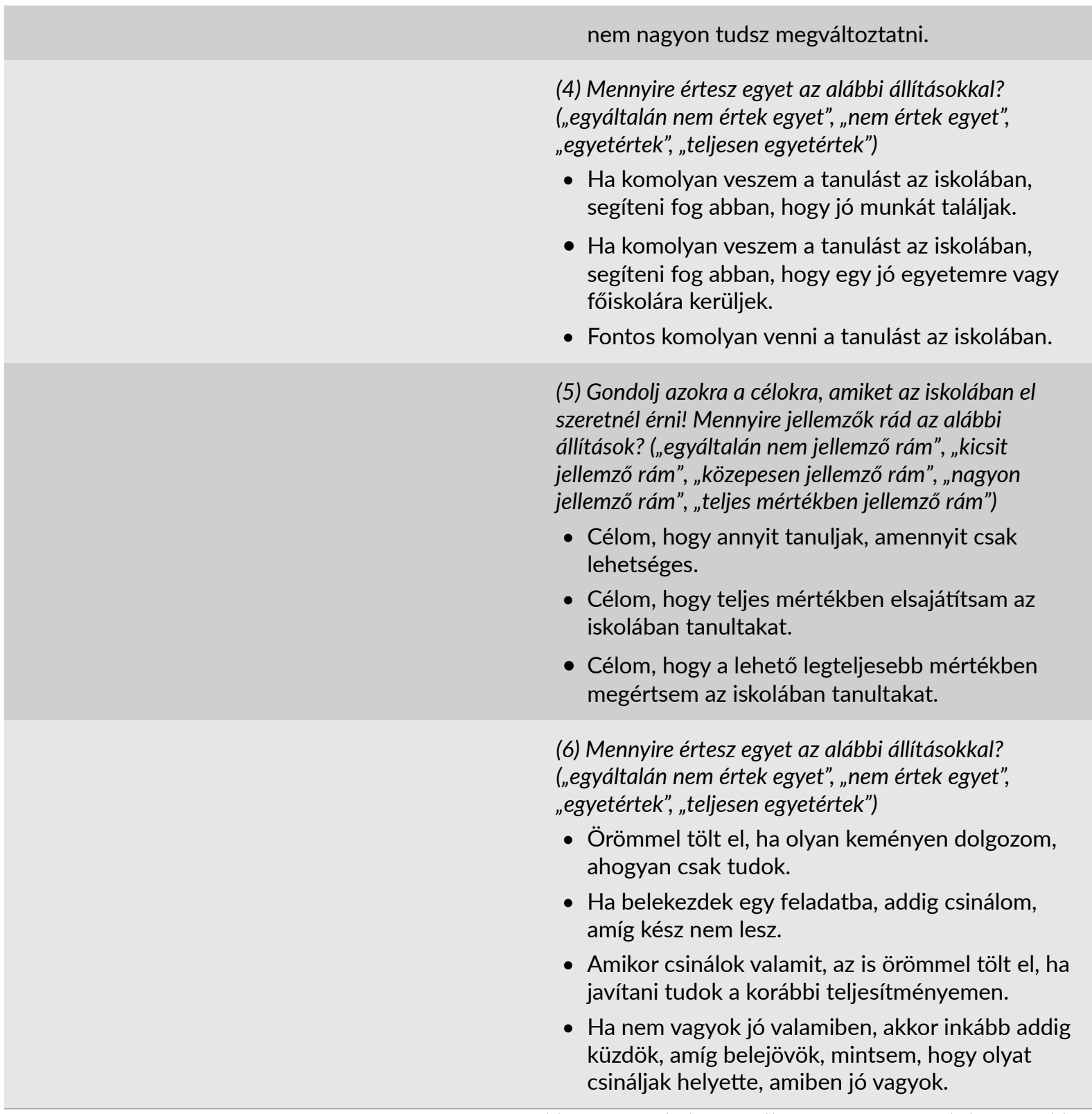

3. táblázat: Pszichológiai jóllét mérése a vizsgált kutatásokban

ISCWEB 2016-2019
HBSC 2017/2018

PISA 2018

\section{Dimenzió}

Szubjektív jóllét: kognitív komponens $=>$ területspecifikus elégedettség (család)
Egészségmagatartás: társas jóllét => család támogatása
Tanulói jóllét: társas dimenzió => szülőkkel való kapcsolat (szülői támogatás)

\section{Alkalmazott kérdés(ek)}

Mennyire értesz egyet az alábbi állitásokkal? („,nem értek egyet”, „kicsit értek egyet”, „valamennyire
Érdekel minket, hogy mi a véleményed az alábbi állításokról. (Kérjük, jelöld meg, hogy mennyire
Mennyire értesz egyet az idei tanévre vonatkozó alábbi állításokkal? („egyáltalán nem értek egyet”, „nem 
egyetértek”, „nagyon egyetértek”, „teljesen egyetértek)

- Vannak a családomban, akik törődnek velem.

- Ha bajom van, a családtagjaim segítenek nekem.

- A családomban jól érezzük magunkat együtt.

- Biztonságban érzem magam otthon.

- A szüleim meghallgatnak és figyelembe veszik, amit mondok.

- A szüleim és én együtt döntünk az életem dolgairól. (csak a 1012 éveseknél)

Mennyire vagy elégedett azokkal az emberekkel, akikkel együtt élsz? (1-5 skála a 8 éveseknél, 0-10 skála a 10-12 éveseknél) (CW-DBSWBS része) értesz velük egyet!) (1 - egyáltalán nem értek egyet, 7 - teljesen egyetértek)

- A családom tényleg próbál segíteni nekem.

- A családomtól megkapom azt az érzelmi támogatást és törődést, amire szükségem van.

- Tudok beszélgetni a gondjaimról a családommal.

- A családom szívesen segít nekem meghozni a döntéseimet. értek egyet”, „egyetértek”, „teljesen egyetértek")

- A szüleim támogatják a tanulmányi igyekezetemet és eredményeimet.

- A szüleim támogatnak, amikor nehézségekkel találom szemben magam az iskolában.

- A szüleim biztatnak, hogy legyek magabiztos.
[Választható kérdőív] Mennyire vagy elégedett a következőkkel? „egyáltalán nem vagyok elégedett”, „, nem vagyok elégedett”, „elégedett vagyok”, ,teljes mértében elégedett vagyok")

Szüleiddel/gondviselóiddel való kapcsolatoddal

[Választható kérdőív] Szüleid/ gondviselöid milyen gyakran teszik az alábbiakat? (,szinte soha”, „néha”, „szinte mindig”)

- Annyi segítséget nyújtanak, amennyire szükségem van.

- Engedik, hogy tegyem a dolgokat, amiket szeretek.

- Kimutatják, hogy törődnek velem.

- Megpróbálják megérteni a problémáimat és aggodalmaimat.

- Bátorítanak, hogy önállóan hozzak döntést.

- Mindent iránytani próbálnak, amit teszek.

- Úgy bánnak velem, mintha kisgyerek lennék.

- Megtesznek mindent, hogy jobban érezzem magam, mikor ideges vagyok.

[Választható kérdőiv] Mennyire könnyü beszélned a téged zavaró dolgokról a következő emberekkel? („nagyon nehéz”, ,nehéz”, „könnyü”, „,nagyon könnyü", „, nincs ilyen személy/ nem találkozom ezzel a személlyel") 


\begin{tabular}{ll}
\hline & • Édesapád \\
& • Édesanyád partnere \\
& • Édesanyád \\
& $\bullet$ Édesapád partnere \\
• Fiútestvére(i)d & - Lánytestvére(i)d \\
& - Más családtagok \\
\hline
\end{tabular}

4. táblázat: Családi élet mérése a vizsgált kutatásokban

\section{Dimenzió}

Szubjektív jóllét: kognitív komponens $=>$ területspecifikus elégedettség (barátok)
Egészségmagatartás: társas jóllét => kortársak támogatása
Tanulói jóllét: társas dimenzió => kortárskapcsolatok (barátok iránti elköteleződés)
Mennyire értesz egyet az alábbi állíásokkal? („,nem értek egyet”, „kicsit értek egyet”, „valamennyire egyetértek”, "nagyon egyetértek”, „teljesen egyetértek)

- Van elég barátom.

- A barátaim általában kedvesek velem.

- A barátaim és én jól kijövünk egymással.

- Van olyan barátom, aki segít, ha bajom van.

\section{Alkalmazott kérdés(ek)}

Érdekel minket, hogy mi a véleményed az alábbi állításokról. (Kérjük, jelöld meg, hogy mennyire értesz velük egyet!) (1 - egyáltalán nem értek egyet, 7 - teljesen egyetértek)

- A barátaim tényleg próbálnak segíteni nekem.

- Ha a dolgok rosszul mennek, számíthatok a barátaimra.

- Vannak barátaim, akikkel megoszthatom az örömömet és a bánatomat.

- Tudok beszélgetni a problémáimról a barátaimmal.
- [Választható kérdőív] A következő kérdések a közeli barátaiddal való kapcsolataidra vonatkoznak. Közeli barátok azok, akikkel bármiröl beszélgethetsz, és akikre számíthatsz, ha segítségre vagy támogatásra van szükséged. Jelenleg hány közeli barátod van? (Kérjük, írd be a megfelelő számot.)
Mennyire vagy elégedett $a$ barátaiddal? (1-5 skála a 8 éveseknél, 0-10 skála a 10-12 éveseknél) (CW-DBSWBS része)
[Választható kérdőív] Mennyire vagy elégedett a következőkkel? „egyáltalán nem vagyok elégedett”, "nem vagyok elégedett”, "elégedett vagyok”, "teljes mértében elégedett vagyok")

Barátaiddal

[Választható kérdőiv] Mennyire könnyű beszélned a téged zavaró dolgokról a következő emberekkel? („,nagyon nehéz”, „nehéz”, „könnyü”, „nagyon könnyü”, „nincs ilyen személy/ nem találkozom ezzel a személlyel")

- Közeli barátod/barátaid 


\section{Dimenzió}

Szubjektiv jóllét: kognitiv komponens $=>$ területspecifikus elégedettség (iskola)
Egészségmagatartás: iskolai élet => iskolával való elégedettség (iskola szeretete, iskolai nyomás)
Tanulói jóllét: pszichológiai dimenzió => karrier- és tanulmányi tervek

\section{Alkalmazott kérdés(ek)}

Mennyire vagy elégedett $a$ következőkkel? (1-5 skála a 8 éveseknél, 0-10 skála a 10-12 éveseknél)

- Azzal, hogy általában milyen iskolásnak lenni. (CW-DBSWBS része)

- Azokkal a dolgokkal, amiket az iskolában tanultál.

Mennyire értesz egyet az alábbi állitásokkal? („nem értek egyet”, "kicsit értek egyet", "valamennyire egyetértek", „nagyon egyetértek”, „teljesen egyetértek)

- Az iskolában van lehetőségem dönteni olyan dolgokról, amik fontosak nekem. (csak a 10 és 12 éveseknél)

- Biztonságban érzem magam az iskolában
- Hogyan érzel az iskolád iránt? Szereted az iskoládat? („nagyon szeretem”, „egy kicsit szeretem”, „nem nagyon szeretem", „egyáltalán nem szeretem”)
[Választható kérdőív] Mennyire vagy elégedett a következőkkel? "egyáltalán nem vagyok elégedett", „nem vagyok elégedett”, „elégedett vagyok”, "teljes mértében elégedett vagyok")

- Életeddel az iskolában

- Azokkal a dolgokkal, amiket az iskolában tanulsz.

Mennyire nyomasztanak téged az iskolai feladatok? („,egyáltalán nem”, „egy kicsit”, „eléggé”, „,nagyon”)
Gondolj a legutóbbi két magyar nyelv- és irodalomórádra! Mennyire értesz egyet az alábbi állításokkal? („egyáltalán nem értek egyet”, „nem értek egyet”, , egyetértek”, "teljesen egyetértek")

- A tanár megerősített engem abban, hogy képes vagyok jól teljesíteni a tantárgyból.

- A tanár meghallgatta a nézetemet arról, hogy hogyan menjenek a dolgok.

- Éreztem, hogy a tanárom megértett engem. 


\section{Dimenzió}

Szubjektív jóllét: kognitív komponens $=>$ területspecifikus elégedettség (osztálytársak)

Egészségmagatartás: iskolai élet => osztálytársak támogatása

\section{Alkalmazott kérdés(ek)}

Mennyire értesz egyet az alábbi állításokkal? („nem értek egyet”, „kicsit értek egyet”, ,valamennyire egyetértek”, "nagyon egyetértek”, „teljesen egyetértek)

- Ha valami bajom van az iskolában, a többi gyerek segít nekem.

- Sok vita van a gyerekek között az osztályomban.
Kérjük, jelöld meg, hogy mennyire értesz egyet az osztálytársaidra vonatkozó következő álításokkal! (1 - teljesen egyetértek, 5 egyáltalán nem értek egyet)

- Osztályom tanulói szívesen vannak együtt.

- Osztálytársaim többsége kedves és segítőkész.

- Osztálytársaim elfogadnak olyannak, amilyen vagyok.
Iskolai klíma/Tanulói jóllét: társas dimenzió => iskolához való tartozás érzése
Mennyire értesz egyet az alábbi, az iskoláddal kapcsolatos állításokkal? („egyáltalán nem értek egyet”, „nem értek egyet”, „egyetértek”, „teljesen egyetértek")

- Az iskolában kívülállónak érzem magam (kihagynak dolgokból).

- Könnyen barátkozom az iskolában.

- Az iskolában úgy érzem, ide tartozom.

- Kényelmetlenül, nem ide valónak érzem magam az iskolában.

- Úgy tünik, a többi tanuló az iskolában kedvel engem.

- Magányosnak érzem magam az iskolában.

\section{Dimenzió}

- Szubjektív jóllét: kognitív komponens $=>$ területspecifikus elégedettség (kortársbántalmazás)
Egészségmagatartás:

kortársbántalmazás és verekedés

=> áldozattá válás/bántalmazás elkövetése
- Iskolai klíma/Tanulói jóllét: tanulói destruktív viselkedés/kortárskapcsolatok => kortársbántalmazás

\section{Alkalmazott kérdés(ek)}

Az elmúlt hónapban milyen gyakran történtek meg veled a következő dolgok? („soha”, „egyszer”, „kétszer vagy háromszor”, „több, mint háromszor")

- Másik gyerek megütött az iskolában csak úgy (nem számít ide, ha verekedtetek, akár játékosan, akár komolyan).

- Másik gyerek csúfolt, gúnynéven nevezett az
Az elmúlt néhány hónapban milyen gyakran bántalmaztak így téged az iskolában? („,az elmúlt hónapokban egyszer sem bántalmaztak az iskolában”, "előfordult 1-2-szer”, "havonta 23-szor", „kb. hetente”, "hetente többször is")
Az elmúlt 12 hónap alatt milyen gyakran élted át az alábbiakat az iskolában? (Az élmények közül néhányra közösségi oldalakon is sor kerülhetett.) ("soha vagy szinte soha", - „évente néhányszor”, „havonta néhányszor”, "hetente egyszer vagy többször")

- Diáktársaim szándékosan kihagytak dolgokból.

- Diáktársaim nevetségessé tettek. 
iskolában.

- Az osztálytársaid kihagytak valamiből, kiközösítettek.

- Diáktársaim megfenyegettek.

- Diáktársaim elvették vagy tönkretették a dolgaimat.

- Diáktársaim megütöttek vagy erőszakoskodtak velem.

Diáktársaim rosszindulatú pletykákat terjesztettek rólam.

Te hogy látod, milyen gyakran van verekedés a gyerekek között az iskoládban? (,soha”, „ritkábban, mint hetente", "egyszer vagy kétszer egy héten", "háromszor vagy négyszer egy héten”, "ötször vagy hatszor egy héten”, "minden nap"; csak a 10 és 12 éveseknél)
Az elmúlt hónapokban milyen gyakran bántottak téged az interneten (pl. bántó üzeneteket küldtek neked sms-ben, chatprogramon keresztül vagy emailben; vagy ilyen üzenetet tettek ki a faladra egy közösségi oldalon; téged gúnyoló weboldalt hoztak létre; kellemetlen vagy kínos képet készítettek rólad és az engedélyed nélkül feltették az internetre? (,,az elmúlt hónapokban egyszer egyszer sem bántalmaztak az interneten", „elöfordult 1-2-szer", ,havonta 23-szor", ,kb. hetente", ,hetente többször is")
Mennyire értesz egyet az idei tanévre vonatkozó alábbi állitásokkal? („,egyáltalán nem értek egyet", "nem értek egyet", "egyetértek", „teljesen egyetértek")

- Idegesít, ha senki sem védi meg azokat a tanulókat, akiket piszkálnak vagy megfélemlítenek.

- Jó dolog segíteni azoknak a tanulóknak, akik nem tudják megvédeni magukat.

- Rossz dolog bekapcsolódni valaki szekálásába vagy megfélemlítésébe.

- Elszomorít, amikor azt látom, hogy más tanulókat piszkálnak vagy megfélemlítenek.

- Szeretem, amikor valaki kiáll azon tanulók mellett, akiket piszkálnak vagy megfélemlítenek.

Az elmúlt néhány hónapban te milyen gyakran vettél részt mások bántalmazásában az iskolában? („,az elmúlt hónapokban egyszer sem vettem részt mások bántalmazásában”, „előfordult 12-szer”, ,havonta 2-3-szor", „kb. hetente", "hetente többször is")

Az elmúlt néhány hónapban te milyen gyakran vettél részt internetes bántalmazásban (pl. bántó üzeneteket küldtél smsben, chatprogramon keresztül, emailben valakinek vagy ilyen bántó üzeneteket tettél ki a falára egy közösségi oldalon; létrehoztál egy weboldalt, hogy kigúnyoljál valakit; kellemetlen vagy kínos képeket tettél fel valakiröl az internetre vagy küldted el mások- 


nak anélkül, hogy a képen
szereplö megengedte volna
neked)? („az elmúlt hónapokban
egyszer sem vettem részt az
interneten mások
bántalmazásában”, „elöfordult 1-
2-szer”, „, havonta 2-3-szor”, „kb.
hetente”, „hetente többször is”)
7. táblázat: Iskolatársakkal való kapcsolatok mérése a vizsgált kutatásokban

\section{Dimenzió}

Szubjektív jóllét: kognitív komponens $=>$ területspecifikus elégedettség (pedagógusok)
Egészségmagatartás: iskolai élet => pedagógusok támogatása
Iskolai klíma/Tanulói jóllét: tanári támogatás és pedagógiai gyakorlat/társas dimenzió => pedagógusokkal való kapcsolat

\section{Alkalmazott kérdés(ek)}

Mennyire értesz egyet az alábbi állításokkal? („nem értek egyet”, „kicsit értek egyet”, ,valamennyire egyetértek”, „nagyon egyetértek”, „teljesen egyetértek)

- A tanáraim törődnek velem.

- Ha valami bajom van az iskolában, a tanáraim segítenek nekem.

- A tanáraim meghallgatnak és figyelembe veszik, amit mondok.
A következő állítások a tanáraidra vonatkoznak. Kérjük, jelöld meg, mennyire értesz egyet velük! (1 teljesen egyetértek, 5 - egyáltalán nem értek egyet)

- Tanáraim elfogadnak olyannak, amilyen vagyok.

- Tanáraim személy szerint törődnek velem.

- Nagyon megbízom a tanáraimban.
Gondolj a legutóbbi két magyar nyelv- és irodalomórádra! Mennyire értesz egyet az alábbi állításokkal? („egyáltalán nem értek egyet”, „nem értek egyet”, „egyetértek”, „teljesen egyetértek")

- A tanár megerősített engem abban, hogy képes vagyok jól teljesíteni a tantárgyból.

- A tanár meghallgatta a nézetemet arról, hogy hogyan menjenek a dolgok.

- Éreztem, hogy a tanárom megértett engem.

Milyen gyakran fordulnak elő az alábbiak a magyar nyelv- és irodalomóráidon? („Minden órán”, „a legtöbb órán”, „néhány órán”, „soha vagy nagyon ritkán")

- A tanár érdeklődést mutat minden tanuló tanulása iránt.

- A tanár külön segítséget nyújt, ha a tanulóknak szükségük van rá.

- A tanár segít a tanulóknak a tanulásban.

- A tanár addig magyarázza az anyagot, amíg minden tanuló 


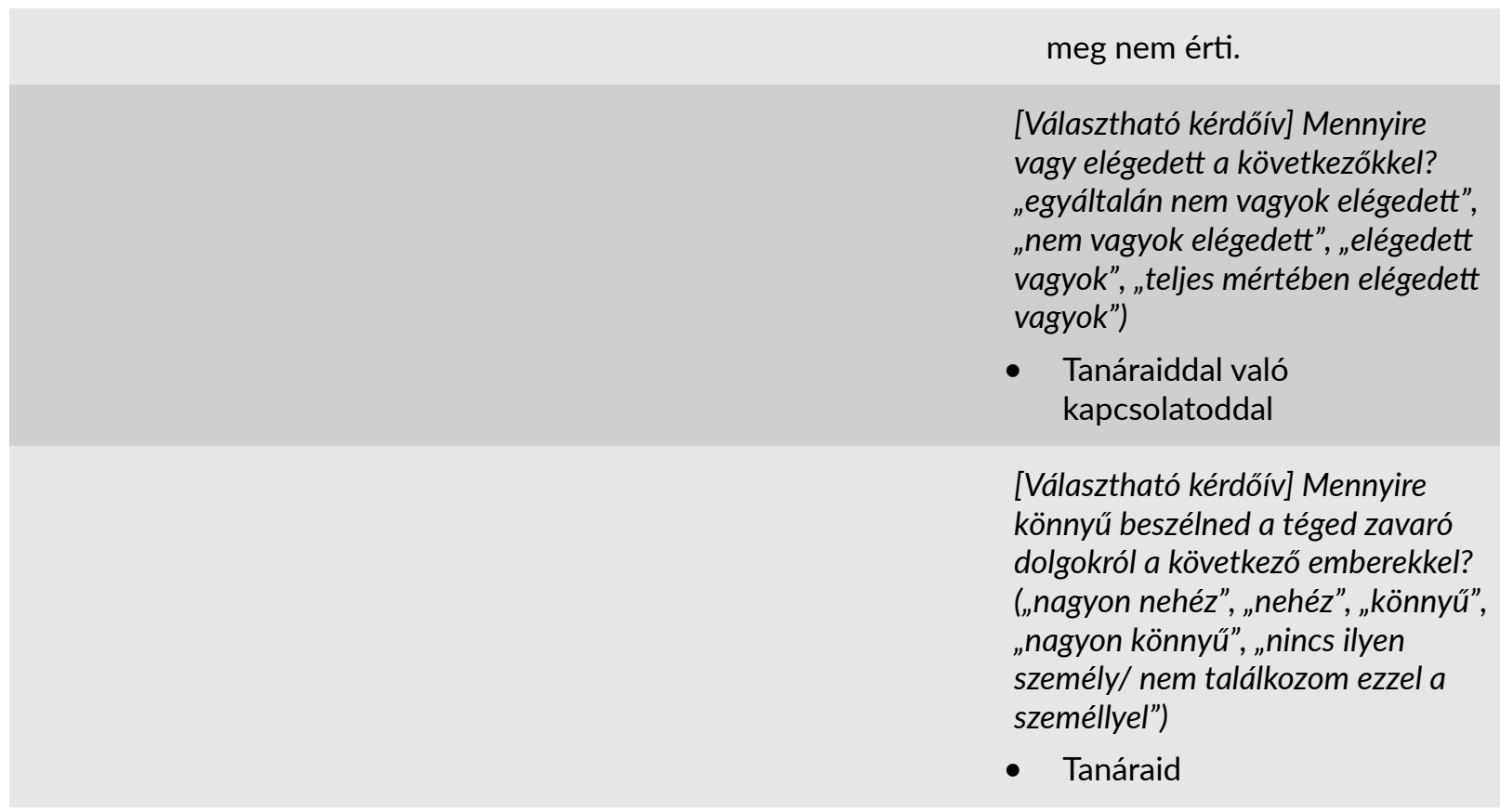

8. táblázat: Pedagógusokkal való kapcsolatok mérése a vizsgált kutatásokban

\section{Dimenzió}

Szubjektív jóllét: kognitív komponens $=>$ területspecifikus elégedettség (egészség, egészségügyi panaszok)
Egészségmagatartás: mentális jóllét => önminősített egészségi állapot, egészségügyi panaszok
Tanulói jóllét: fizikai dimenzió => egészség

\section{Alkalmazott kérdés(ek)}

Mennyire vagy elégedett $a$ következőkkel? (1-5 skála a 8 éveseknél, 0-10 skála a 10-12 éveseknél)

- Az egészségeddel.
[Választható kérdőív] Mennyire vagy elégedett a következőkkel? "egyáltalán nem vagyok elégedett", „ „nem vagyok elégedett", „elégedett vagyok”, "teljes mértében elégedett vagyok")

- Az egészségeddel.

Szerinted milyen az egészséged? („kitünö”, „jó", „,megfelelö”, „rossz")

Az elmúlt 6 hónapban milyen gyakran érezted a következőket? (,szinte naponta”, ,hetente többször", „kb. hetente”, „kb. havonta", „ritkábban vagy soha”) - Fájt a fejem.

- Fájt a gyomrom vagy a hasam.
- [Választható kérdőív] Szerinted milyen az egészséged? („kitünő", "jó", „,megfelelö", ,rossz")

[Választható kérdőív] Az elmúlt 6 hónapban milyen gyakran tapasztaltad a következöket? („ritkábban vagy soha”, „kb. havonta”, „kb. hetente”, "hetente többször”, „szinte naponta”)

- Fejfájás 
- Fájt a gyomrom vagy a hasam.

- Fájt a hátam.

- Kedvetlen, rosszkedvú voltam.

- Ingerlékeny, indulatos, veszekedős voltam.

- Ideges voltam.

- Nem tudtam elaludni.

- Szédültem.

- Fáradt, kimerült voltam.

- Nem volt étvágyam.
- Fájt a hátam.

- Kedvetlen, rosszkedvú voltam.

- Ingerlékeny, indulatos, veszekedős voltam.

- Ideges voltam.

- Nem tudtam elaludni.

- Szédültem.

- Fáradt, kimerült voltam. (Ez az item csak a magyar adatfelvételben szerepelt.)
- Has- vagy gyomorfájás

- Hátfájás

- Kedvetlenség, rosszkedvűség

- Ingerlékenység, indulatosság

- Idegesség

- Elalvási nehézségek

- Szédülés

- Szorongás

9. táblázat: Egészségi állapot mérése a vizsgált kutatásokban

HBSC 2017/2018

PISA 2018

\section{Dimenzió}

Szubjektív jóllét: kognitiv komponens $=>$ területspecifikus elégedettség (megjelenés)
Egészségmagatartás: tápláltsági állapot, testkép
Tanulói jóllét: fizikai dimenzió => testkép

\section{Alkalmazott kérdés(ek)}

Mennyire vagy elégedett a következőkkel? (1 -5 skála a 8 éveseknél, 0-10 skála a 10-12 éveseknél)

- Azzal, ahogyan kinézel. (CWDBSWBS része)
Milyennek tartod magad? („túl soványnak”, „egy kicsit soványnak”, vagy elégedett a következőkkel? „kb. megfelelőnek”, „egy kicsit kövérnek”, „túl kövérnek”) egyáltalán nem vagyok elégedett”, „nem vagyok elégedett”, „elégedett vagyok”, „teljes mértében elégedett vagyok")

- Azzal, ahogyan kinézel.

Hány kg vagy ruha nélkül? Hány centi magas vagy cipö nélkül?
- [Választható kérdőív] Mekkora a súlyod? Milyen magas vagy?

[Választható kérdőív] Mennyire értesz egyet az alábbi állításokkal? („egyáltalán nem értek egyet”, „, nem értek egyet”, „egyetértek”, „teljesen egyetértek)

- Úgy tetszik a külsőm, amilyen.

- Vonzónak, helyesnek tartom magam.

- Nem aggódom a súlyom miatt.

- Szeretem a testem.

- Tetszik, ahogy a ruháim állnak magamon.

10. táblázat: Szubjektív és objektív testkép mérése a vizsgált kutatásokban 


\section{Three international studies on student well-being: A conceptual comparison}

In the last decade, there has been growing research interest in children's well-being. This is especially true for studies in the context of education, school. The main purpose of the study is to provide a comprehensive picture of the possible research dimensions of students' subjective well-being. To this end, the study compares the framework for the analysis of student well-being of three international surveys (ISCWeB, HBSC, PISA), as well as the dimensions of student well-being examined in recent surveys. All three international surveys use a multidimensional framework for the analysis of student well-being so that many common areas appear in their data collection (overall life satisfaction, emotional state, psychological well-being, family life, friendships, school life, health status, subjective and objective body image). The results of the comparison show that the questions related to well-being in the surveys are not fully the same in all cases, in several cases only content and functional matching is possible. Besides, the age of the students surveyed, and the context of issues related to student well-being also differ in these surveys. There is a difference in the number of questions or items related to dimensions, in the scales of the given answer options, as well as in the time intervals that are questioned. Nevertheless, our study is a first step in the direction of exploring a more reliable and valid picture of students' well-being in a later analysis, especially about Hungarian characteristics, based on the results of these international surveys.

Keywords: student well-being, well-being dimensions, international comparison, ISCWeB, HBSC, PISA 